\title{
Characterization of the long-term radiosonde temperature biases in the upper troposphere and lower stratosphere using COSMIC and Metop-A/GRAS data from 2006 to 2014
}

\author{
Shu-peng Ho ${ }^{1}$, Liang Peng ${ }^{1}$, and Holger Vömel ${ }^{2}$ \\ ${ }^{1}$ COSMIC Project Office, University Corporation for Atmospheric Research, Boulder, CO, USA \\ ${ }^{2}$ National Center for Atmospheric Research, Boulder, CO, USA
}

Correspondence to: Shu-Peng Ho (spho@ucar.edu)

Received: 7 September 2016 - Discussion started: 12 October 2016

Revised: 6 February 2017 - Accepted: 28 February 2017 - Published: 4 April 2017

\begin{abstract}
Radiosonde observations (RAOBs) have provided the only long-term global in situ temperature measurements in the troposphere and lower stratosphere since 1958. In this study, we use consistently reprocessed Global Positioning System (GPS) radio occultation (RO) temperature data derived from the COSMIC and Metop-A/GRAS missions from 2006 to 2014 to characterize the inter-seasonal and interannual variability of temperature biases in the upper troposphere and lower stratosphere for different radiosonde sensor types. The results show that the temperature biases for different sensor types are mainly due to (i) uncorrected solarzenith-angle-dependent errors and (ii) change of radiation correction. The mean radiosonde-RO global daytime temperature difference in the layer from 200 to $20 \mathrm{hPa}$ for Vaisala RS92 is equal to $0.20 \mathrm{~K}$. The corresponding difference is equal to $-0.06 \mathrm{~K}$ for Sippican, $0.71 \mathrm{~K}$ for VIZ-B2, $0.66 \mathrm{~K}$ for Russian AVK-MRZ, and 0.18 K for Shanghai. The global daytime trend of differences for Vaisala RS92 and RO temperature at $50 \mathrm{hPa}$ is equal to $0.07 \mathrm{~K} / 5 \mathrm{yr}$. Although there still exist uncertainties for Vaisala RS92 temperature measurement over different geographical locations, the global trend of temperature differences between Vaisala RS92 and RO from June 2006 to April 2014 is within $\pm 0.09 \mathrm{~K} / 5 \mathrm{yr}$. Compared with Vaisala RS80, Vaisala RS90, and sondes from other manufacturers, the Vaisala RS92 seems to provide the most accurate RAOB temperature measurements, and these can potentially be used to construct long-term temperature climate data records (CDRs). Results from this study also demonstrate the feasibility of using RO data to correct RAOB temperature biases for different sensor types.
\end{abstract}

\section{Introduction}

Stable, long-term atmospheric temperature climate data records (CDRs) with accurate uncertainty estimates are critical for understanding climate variability and change in both the troposphere and stratosphere and their feedback mechanisms (Thorne et al., 2011; Seidel et al., 2011). Radiosonde observations (RAOBs) have provided the only long-term global in situ temperature, moisture, and wind measurements in the troposphere and lower stratosphere since 1958. Several groups have used multiple years of RAOB temperature measurements to construct long-term CDRs (e.g., Durre et al., 2005; Free et al., 2004, 2005; Sherwood et al., 2008; Haimberger et al., 2008, 2011; Thorne et al., 2011; Seidel et al., 2009). However, it has long been recognized that the quality of the RAOB observations varies for different sensor types and height (e.g. Luers and Eskridge, 1995, 1998; Luers, 1997). Therefore, except for some sensor types where a relatively objective radiation correction had been applied (i.e., Vaisala RS90), it is difficult to objectively identify, trace, and remove most of the sensor-dependent biases for the historical sonde data and use the corrected RAOB temperatures to construct consistent temperature CDRs. The large uncertainties among temperature CDRs constructed from satellite and in situ measurements are still one of the most challenging issues for climate change research (IPCC AR5).

The causes of temperature errors in RAOB sensors include the changing of instruments and practices (Gaffen, 1994) and errors occurring due to the influence of solar and infrared radiation on the thermistor. In the past decade, many homogenization methods have been proposed to identify and correct 
errors due to changing of instruments and practice (Luers and Eskridge, 1998; Lanzante et al., 2003; Andrae et al., 2004; Free et al., 2004, 2005; Sherwood et al., 2008; Haimberger et al., 2008, 2011; Thorne et al., 2011; Seidel et al., 2009). Possible errors due to changes of instruments were identified by comparing with temperature measurements from adjacent weather stations. However, this approach is limited by the low number of co-located observations and large atmospheric variability. In addition, due to lack of absolute references, the remaining radiation temperature biases from adjacent stations may not be completely removed. As a result, only relative temperature differences of a possibly large uncertainty among stations are identified.

To correct possible RAOB temperature errors due to radiative effects, Andrae et al. (2004) and Haimberger et al. (2007, 2008, 2011) calculated temperature differences between observations and reanalyses data which were then used to minimize the differences between daytime and nighttime temperature differences. Nevertheless, because changes of reanalysis systems and possible incomplete calibration of satellite instruments may complicate the temperature bias correction, long-term stability of the derived temperature trends is still of great uncertainty. To correct the RAOB solar/infrared radiation errors, radiation correction tables (for example, RSN96, RSN2005, and RSN2010 tables from Vaisala) were introduced by manufacturers. However, when and how exactly different countries start to apply these corrections and whether there are remaining uncorrected radiative effects over different geographic regions is still unknown. It is important to use stable and accurate temperature references to characterize these errors from multiple sensors in different geographical regions over a long period of time.

The fundamental observable (time delay) for the Global Positioning System (GPS) radio occultation (RO) satellite remote sensing technique can be traced to ultra-stable international standards (atomic clocks) on the ground. While time delay and bending angles are traceable to the international standard of units (SI traceability), the derived temperature profiles are not. To investigate the structural uncertainty of RO temperature profiles, Ho et al., (2009a, 2011) compared CHAMP (CHAllenging Minisatellite Payload) temperature profiles generated from multiple centers when different inversion procedures were implemented. Results showed that the mean RO temperature biases for one center relative to the all center mean is within $\pm 0.1 \mathrm{~K}$ from 8 to $30 \mathrm{~km}$, except for the South Pole above $25 \mathrm{~km}$.

The mean temperature difference between the collocated soundings of COSMIC (Constellation Observing System for Meteorology, Ionosphere, and Climate) and CHAMP was within $0.1 \mathrm{~K}$ from 200 to $20 \mathrm{hPa}$ (Ho et al., 2009b; Anthes et al., 2008; Foelsche et al., 2009). At $20 \mathrm{hPa}$, the mean temperature difference between COSMIC and CHAMP was within $0.05 \mathrm{~K}$ (Ho et al., 2009b). Schreiner et al. (2014) compared reprocessed COSMIC and Metop-A/GRAS (Meteorological Operational Polar Satellite A/Global Navigation Satellite
System (GNSS) receiver for Atmospheric Sounding) bending angles and temperatures produced at COSMIC Data Analysis and Archive Center (CDAAC). The mean layer temperature difference between 200 to $10 \mathrm{hPa}$ was within $0.05 \mathrm{~K}$ where the mean temperature difference at $20 \mathrm{hPa}$ is equal to $0.03 \mathrm{~K}$. These results demonstrate the consistency of COSMIC and Metop-A/GRAS temperatures.

The precision of RO temperature is $\sim 0.1 \mathrm{~K}$ (Anthes et al., 2008; Ho et al., 2009a), and the precision of the trend of ROderived temperature data is within $\pm 0.06 \mathrm{~K} / 5 \mathrm{yr}$ (Ho et al., 2012). To estimate the uncertainty of RO temperature in the upper troposphere and lower stratosphere, Ho et al. (2010) compared RO temperature from 200 to $10 \mathrm{hPa}$ to those from Vaisala RS92 in 2007 where more than 10000 pairs of coincident Vaisala RS92 and COSMIC data were collected. The mean bias in this height range was equal to $-0.01 \mathrm{~K}$ with a mean standard deviation of $2.09 \mathrm{~K}$. At $20 \mathrm{hPa}$, the mean bias was equal to $-0.02 \mathrm{~K}$. These comparisons demonstrate the quality of RO temperature profiles in this height range.

RO-derived atmospheric variables have been used as reference to identify RAOB sensor-dependent biases. For example, Kuo et al. (2004) used RO data to identify sensortype-dependent refractivity biases. Ho et al. (2010a) demonstrated that RO-derived water vapor profiles can be used to distinguish systematic biases among humidity sensors. He et al. (2009) and Sun et al. (2010, 2013) used RO temperature data in the lower stratosphere to quantify the temperature biases for several sensor types. While He et al. (2009) used the COSMIC post-processed temperature profiles from $\mathrm{Au}$ gust 2006 to February 2007 to quantify the radiosonde radiation temperature biases for different sensor types, Sun et al. (2010, 2013) used COSMIC real-time processed temperature profiles to identify radiosonde temperature biases for numerical weather prediction (NWP) analysis. Because complete GPS orbital information is not available in real time, approximate GPS orbital information was used in the real-time inversion processing. The differences between real-time and post-processed RO temperatures in the lower stratosphere range from 0.3 to $0.1 \mathrm{~K}$ depending on the comparison period. Although real-time COSMIC data, which are processed by using periodically revised inversion packages, may be suitable for weather analysis, they may not be suitable for climate studies. Both of these RAOB-RO comparisons are constructed from a relatively limited period of time. A consistent validation of the variability of inter-seasonal and interannual RAOB temperature biases over a longer time period (close to 10 years) for different temperature sensor types has not yet been done.

Recently, the UCAR CDAAC has developed an improved reprocessing package, which is used to consistently process RO data from multiple years of multiple RO missions including COSMIC (launched in April 2006) and Metop-A/GRAS (launched in October 2006). A sequence of processing steps is used to invert excess phase measurement to retrieve atmo- 
spheric variables including bending angle, refractivity, pressure, temperature, and geopotential height.

The new inversion package uses improved precise orbit determination (POD) and excess phase processing algorithm, where a high-precision, multiple GNSS data processing software (i.e., Bernese Version 5.2; Dach et al., 2015) is applied for clock estimation and time transfer. In the reprocessing package, the POD for COSMIC and Metop-A/GRAS is implemented separately (Schreiner et al., 2011). The reprocessed RO data produce more consistent and accurate RO variables than those from post-processed (periodically updated inversion packages were used) and real-time processed datasets.

The objectives of this study are to use consistently reprocessed GPS RO temperature data to characterize (i) temperature biases dependent on solar zenith angle (SZA), (ii) potential residual temperature errors due to incomplete radiation correction, (iii) temperature biases due to change of radiation correction over different geographical regions, (iv) the inter-seasonal and interannual variability of these temperature biases, and (v) the trends of these biases and their uncertainty for different sensor types in the upper troposphere and lower stratosphere. In contrast to previous studies (i.e., He et al., 2009, and Sun et al., 2010, 2013) that used shorter time periods, close to 8 years (from June 2006 to April 2014) of consistently reprocessed temperature profiles derived from COSMIC and Metop-A/GRAS are used. Because the quality of RO data does not change during the day or night and is not affected by clouds (Anthes et al., 2008), the RO temperature profiles co-located with RAOBs are useful for identifying the variation of temperature biases over time of different temperature sensors.

In Sect. 2, we describe the RO and RAOB data and the comparison method. The global comparison of RAOBRO pairs for different temperature sensor types for daytime and nighttime is summarized in Sect. 3. The global SZAdependent temperature biases for various sensor types at different geographical regions are also compared in this section. The inter-seasonal variations of RAOB-RO temperature biases are assessed in Sect. 4. We conclude our study in Sect. 5 .

\section{Data and comparison method}

\subsection{RAOB data}

The radiosonde data used in this study were downloaded from CDAAC (https://rda.ucar.edu/datasets/ds351.0/). The data include the temperature, pressure, and moisture profiles generated from the original radiosonde data in the NCAR data archive (http://rda.ucar.edu/datasets/ds351.0), which provides global radiosonde data with the detailed instrument type.

There are more than 1100 radiosonde stations globally. Figure 1 depicts the geophysical locations for all RAOB data from June 2006 to April 2014. These include Vaisala RS80, RS90, RS92, AVK-MRZ (and other Russian sondes), VIZB2, Sippican MARK II A, Shanghai (from China), and Meisei (Japan). Table 1 summarizes the availability for different instrument types. In total, 17 different types of radiosonde systems were used. The solar absorptivity $(\alpha)$ and sensor infrared emissivity $(\varepsilon)$ for the corresponding thermocap and thermistor for different instrument types are also summarized in Table 1. Most of the radiosonde data are collected twice per day.

Because the Vaisala RS80 sensor was never changed and should be the same for all RS80 models and the software uses the same radiation correction table that should not show any differences, we do not further separate Vaisala RS80 sensors (i.e., $\mathrm{ID}=37,52,61$, and 67 ). For the same reason, all RS92 sensors (ID $=79,80,81)$ are summarized together and all Russian sensors (ID $=27,75,88,89,58)$ are summarized as AVK sonde (see Table 2 and Sect. 3.1).

\subsection{GPS RO data}

The reprocessed COSMIC (Version 2013.3520) and MetopA/GRAS (Version 2016.0120) dry temperature profiles downloaded from UCAR CDAAC (http://cdaac-www. cosmic.ucar.edu/cdaac/products.html) are used in this study. With six GPS receivers on board six LEO satellites, COSMIC produced about 1000 to 2500 RO profiles per day for the launch in April 2006 through 2014 (the number has been declining since 2014 as the satellites have aged beyond their design lifetime of 5 years). With one receiver, Metop-A/GRAS produced about 600 RO profiles per day. The detailed inversion procedures of COSMIC Version 2013.3520 and Metop-A Version 2016.0120 are summarized at http://cdaac-www.cosmic.ucar.edu/cdaac/ doc/documents/Sokolovskiy_newroam.pdf. The general description of CDAAC inversion procedures is described in Kuo et al. (2004) and Ho et al. (2009a, 2012). In a neutral atmosphere, the refractivity $(\mathrm{N})$ is related to pressure $(P$ in $\mathrm{hPa}$ ), temperature ( $T$ in $\mathrm{K}$ ), and the water vapor pressure $(e$ in hPa) according to Smith and Weintraub (1953):

$N=77.6 \frac{P}{T}+3.73 \times 10^{5} \frac{e}{T^{2}}$.

Because moisture in the upper troposphere and stratosphere is negligible, the dry temperature is nearly equal to the actual temperature (Ware et al., 1996). In this study, we use RO dry temperature from 200 to $20 \mathrm{hPa}$ to quantify the temperature biases for different sensor types.

\subsection{Detection of RAOB temperature biases using RO data over different geographical regions}

The RO atmPrf data from COSMIC and Metop-A/GRAS were first interpolated to the mandatory pressure level of the radiosondes (i.e., 200, 150, 100, 50, and $20 \mathrm{hPa}$ ). To account 


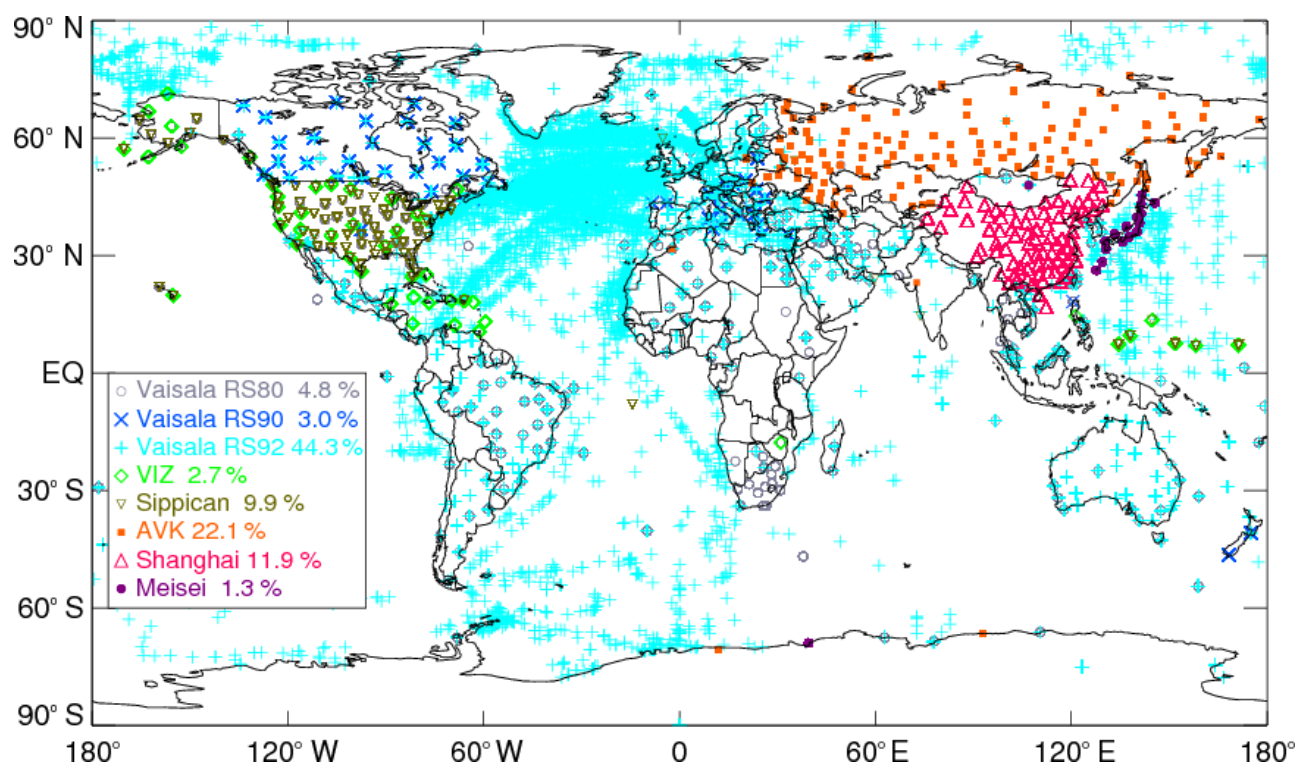

Figure 1. Global distribution of radiosonde stations colored by radiosonde types. Radiosonde types updated from June 2006 to April 2014 are used. The percentage of each type of radiosonde used among all stations is listed. For those stations that radiosonde types are changed during this period, the latest updated radiosonde type is used in this plot. Vaisala RS92 ship observations contain less than $3 \%$ of the total RS92 profiles.

for the possible temporal and spatial mismatches between RO data and RAOBs, the RO data within $2 \mathrm{~h}$ and $300 \mathrm{~km}$ of the radiosonde data were collected for different RAOB instrument types. These matching criteria are similar to the criteria used by $\mathrm{He}$ et al. (2009). However, in contrast to He et al. (2009), positions of RO measurements at the corresponding heights are used in the RAOB-RO ensembles. We compute temperature differences between RO atmPrf and the corresponding RAOB pairs in the same pressure level $i$ using the equation

$$
\Delta T(i, j)=\left(\frac{1}{n}\right) \times \sum_{s=1}^{s=n}\left\{T_{\mathrm{RAOB}}(i, j, s)-T_{\mathrm{RO}}(i, j, s)\right\},
$$

where $j$ is the index for 18 instrument type listed in Table 1, and $s$ is the index for all the matched pairs for each of 17 instrument types.

In addition, we compare the monthly mean temperature biases $\Delta T^{\text {Time }}$ for the matched pairs at different geographical regions from

$\Delta T^{\text {Time }}(l, m, k)=T_{\mathrm{RAOB}}(l, m, k)-T_{\mathrm{RO}}(l, m, k)$,

where $l, m$, and $k$ are the indices of the month bin for each vertical grid, zone, and month for the whole time series ( $k=1$ to 95), respectively, from June 2006 to April 2014. The geographical zones $(m)$ are from USA $(m=1)$, Australia $(m=2)$, Germany $(m=3)$, Canada $(m=4)$, United Kingdom $(m=5)$, Brazil $(m=6)$, Russia $(m=7)$, China $(m=8)$, and Japan $(m=9)$. The standard deviation of the time series is also computed to indicate the variability of $\Delta T^{\text {Time }}$. In this study, daytime data are from SZA from 0 to $90^{\circ}$ and nighttime data are from SZA from 90 to $180^{\circ}$. The SZA is computed from the synoptic launch time and location of sonde station because the time and location of the sonde at different heights are not available.

\section{Global mean RAOB temperature biases for all sensor types identified by RO data}

RS92 (ID $=79,80,81)$ data were used in this study. Since 1981, Vaisala RS80 (from 1981 to 2014), RS90 (from 1995 to 2014), and RS92 have been widely used for NWP and atmospheric studies. For many modern radiosondes (for example RS92) the structural uncertainties are $\pm 0.2 \mathrm{~K}$ below $100 \mathrm{hPa}$ and somewhat higher at higher levels. While the Vaisala data have been corrected for possible radiation errors (see RS92 Data Continuity link under the Vaisala website), some radiation corrections were also made for other sensor types, although they may not be clearly indicated in the Metadata files. We quantify the global mean residual radiation correction biases for all sensor types in this section.

\subsection{The RAOB temperature biases during the daytime and nighttime for all sensor types}

In total, we have more than 600000 RAOB-RO pairs. Using Eq. (2), we compute the temperature biases of radiosonde measurements for each individual sensor type. The mean temperature bias for ensembles of the RAOB-RO pairs from June 2006 to April 2014 for the layer between 200 and $20 \mathrm{hPa}$ for different RAOB sensor types is summarized in Table 2. 
Table 1. Summary of the availability for different instrument types and their solar absorptivity $(\alpha)$ and sensor infrared emissivity $(\varepsilon)$ for the corresponding thermocap and thermistor and the sample number of RAOB-RO pairs used in this study from June 2006 to April 2014.

\begin{tabular}{|c|c|c|c|c|c|c|}
\hline & ID & Sensor type & Availability & $\begin{array}{l}\text { Solar } \\
\text { absorptivity }\end{array}$ & $\begin{array}{r}\text { Infrared } \\
\text { emissivity }\end{array}$ & $\begin{array}{r}\text { Number of } \\
\text { RO-RAOB pairs }\end{array}$ \\
\hline RS80 & 37 & Bead thermocap & 1981-2014 & $\begin{array}{l}0.15 \\
\text { (Luers and } \\
\text { Eskridge, 1998) }\end{array}$ & 0.02 & 1624 \\
\hline Vaisala RS80-57H & 52 & Bead thermocap & $\begin{array}{l}\text { early 1990s- } \\
\text { Jul } 2012 \\
\text { (Redder et al., 2004) }\end{array}$ & 0.15 & 0.02 & 13192 \\
\hline Vaisala RS80/Loran & 61 & Bead thermocap & $\sim 2014$ & 0.15 & 0.02 & 11591 \\
\hline Vaisala RS80/DigiCORA III & 67 & Bead thermocap & $\sim 2012$ & 0.15 & 0.02 & 2864 \\
\hline Vaisala RS90/DigiCORA I, II & 71 & $\begin{array}{l}\text { Thin wire F-thermocap } \\
\text { (Sun et al., 2010) }\end{array}$ & $1995-2014$ & $\begin{array}{l}0.15 \\
\text { (Luers, 1997) }\end{array}$ & 0.02 & 18082 \\
\hline Vaisala RS92/DigiCORA I/II & 79 & $\begin{array}{l}\text { Thin wire F-thermocap } \\
\text { (Sun et al., 2010) }\end{array}$ & $2003-2014$ & 0.15 & 0.02 & 40478 \\
\hline Vaisala RS92/DigiCORA III & 80 & Thin wire F-thermocap & 2004-2014 & 0.15 & 0.02 & 184542 \\
\hline Vaisala RS92/Autosonde & 81 & Thin wire F-thermocap & 2011-2014 & 0.15 & 0.02 & 42577 \\
\hline AVK-MRZ & 27 & $\begin{array}{l}\text { Rod thermistor } \\
\text { (Sun et al., 2010) }\end{array}$ & $\sim 2014$ & $\begin{array}{l}0.2 \\
\text { (He et al., 2009) }\end{array}$ & 0.04 & 48954 \\
\hline $\begin{array}{l}\text { AVK-BAR } \\
\text { (Russian) }\end{array}$ & 58 & Rod thermistor & 2007-2014 & 0.2 & 0.04 & 26020 \\
\hline $\begin{array}{l}\text { AVK-MRZ } \\
\text { (Russian) }\end{array}$ & 75 & Rod thermistor & $\sim 2013$ & 0.2 & 0.04 & 9472 \\
\hline $\begin{array}{l}\text { MARL-A or Vektor-M-MRZ } \\
\text { (Russian) }\end{array}$ & 88 & Rod thermistor & $\sim 2014$ & 0.2 & 0.04 & 23326 \\
\hline $\begin{array}{l}\text { MARL-A or Vektor-M-BAR } \\
\text { (Russian) }\end{array}$ & 89 & Rod thermistor & $\sim 2014$ & 0.2 & 0.04 & 25715 \\
\hline VIZ-B2 & 51 & $\begin{array}{l}\text { Rod thermistor } \\
\text { (Sun et al., 2010) }\end{array}$ & $\begin{array}{l}\text { 1997-2014 } \\
\text { (Elliott et al., 2002) }\end{array}$ & $\begin{array}{l}0.15 \\
\text { (Luers and } \\
\text { Eskridge, 1998) }\end{array}$ & 0.86 & 16310 \\
\hline Sippican MARK II A Chip & 87 & $\begin{array}{l}\text { Chip thermistor } \\
\text { (Sun et al., 2010) }\end{array}$ & $\begin{array}{l}\text { 1998-2014 } \\
\text { (Elliott et al., 2002) }\end{array}$ & $\begin{array}{l}0.07 \\
\text { (Luers and } \\
\text { Eskridge, 1998) }\end{array}$ & 0.85 & 59775 \\
\hline Shanghai & 32 & Rod thermistor & 1998-2012 & $\begin{array}{l}<0.07 \\
(\text { Wei, 2011) }\end{array}$ & $>0.90$ & 71605 \\
\hline Meisei Japan & 47 & $\begin{array}{l}\text { Thermistor } \\
\text { (Kobayashi } \\
\text { et al., 2012) }\end{array}$ & 1994-2013 & $\begin{array}{l}0.18 \\
\text { (Luers and } \\
\text { Eskridge, 1998) }\end{array}$ & 0.84 & 7888 \\
\hline
\end{tabular}

The standard deviations for each radiosonde type are also shown. The radiosonde temperature biases vary for different sensor types. All biases are less than $0.25 \mathrm{~K}$ except for AVK and VIZ-B2, which reach 0.66 and $0.71 \mathrm{~K}$, respectively, during the day.

The solar radiation effect on sensors is the dominant error source of RAOB temperature biases (Luers et al., 1998; He et al., 2009). We assume that all operational data have a radiation correction already applied. The global temperature biases relative to the co-located $\mathrm{RO}$ temperature at $50 \mathrm{hPa}$ for various radiosonde sensor types for daytime and nighttime are shown in Fig. 2. Only those stations containing more than 50 RAOB-RO pairs are plotted. Figure 2a shows biases for different sensor types, which vary with geographical re- gion. Most of the sensor types contain positive temperature biases ranging from 0.1 to $0.6 \mathrm{~K}$ during the daytime. This bias during daytime may be a result of the residual error of the systematic radiation bias correction. Although we only include stations containing more than 50 RAOB-RO pairs, some level of heterogeneity (i.e., Fig. 2a over Brazil) may be due to low sample sizes. For example, stations with temperature biases larger than $0.5 \mathrm{~K}$ in eastern Brazil contain only about 60 RAOB-RO pairs. The cause of the heterogeneity in temperature bias between North and South China is not certain at this point.

The mean nighttime biases are very different from those in the daytime for the same sensors. Figure $2 b$ shows that most of the sensor types show a cold bias at night except for 
Table 2. Mean and standard deviation (SD) of temperature differences (K) from the layer from 200 to $20 \mathrm{hPa}$ between eight types of radiosonde ${ }^{\mathrm{a}, \mathrm{b}}$ and $\mathrm{RO}$.

\begin{tabular}{|c|c|c|c|c|}
\hline & ID & $\begin{array}{r}\text { All day and } \\
\text { night mean }(\mathrm{SD}) / \\
\text { sample } \\
\text { numbers }\end{array}$ & $\begin{array}{r}\text { Day } \\
\text { mean }(\mathrm{SD}) / \\
\text { sample } \\
\text { numbers }\end{array}$ & $\begin{array}{r}\text { Night } \\
\text { mean }(\mathrm{SD}) / \\
\text { sample } \\
\text { numbers }\end{array}$ \\
\hline Vaisala RS80 & $37,52,61,67$ & $\begin{array}{r}0.10 \\
(1.54) / 29271\end{array}$ & $\begin{array}{r}0.10 \\
(1.53) / 15947\end{array}$ & $\begin{array}{r}0.09 \\
(1.55) / 13324\end{array}$ \\
\hline Vaisala RS90 & 71 & $\begin{array}{r}0.13 \\
(1.54) / 18082\end{array}$ & $\begin{array}{r}0.16 \\
(1.51) / 8758\end{array}$ & $\begin{array}{r}0.11 \\
(1.57) / 9324\end{array}$ \\
\hline Vaisala RS92 & $79,80,81$ & $\begin{array}{r}0.16 \\
(1.52) / 267597\end{array}$ & $\begin{array}{r}0.20 \\
(1.50) / 161019\end{array}$ & $\begin{array}{r}0.09 \\
(1.55) / 106578\end{array}$ \\
\hline AVK & $\begin{array}{l}27,75,88,89 \\
58\end{array}$ & $\begin{array}{r}0.33 \\
(1.58) / 133487\end{array}$ & $\begin{array}{r}0.66 \\
(1.51) / 67679\end{array}$ & $\begin{array}{r}-0.06 \\
(1.56) / 65808\end{array}$ \\
\hline VIZ-B2 & 51 & $\begin{array}{r}0.22 \\
(1.67) / 16310\end{array}$ & $\begin{array}{r}0.71 \\
(1.54) / 9246\end{array}$ & $\begin{array}{r}-0.42 \\
(1.60) / 7064\end{array}$ \\
\hline Sippican MARK IIA Chip & 87 & $\begin{array}{r}-0.08 \\
(1.59) / 59775\end{array}$ & $\begin{array}{r}-0.06 \\
(1.56) / 31230\end{array}$ & $\begin{array}{r}-0.10 \\
(1.62) / 28545\end{array}$ \\
\hline Shanghai & 32 & $\begin{array}{r}0.05 \\
(1.68) / 71605\end{array}$ & $\begin{array}{r}0.18 \\
(1.67) / 33360\end{array}$ & $\begin{array}{r}-0.07 \\
(1.68) / 38245\end{array}$ \\
\hline Meisei Japan & 47 & $\begin{array}{r}0.11 \\
(1.69) / 7888\end{array}$ & $\begin{array}{r}0.03 \\
(1.71) / 3849\end{array}$ & $\begin{array}{r}0.19 \\
(1.66) / 4039\end{array}$ \\
\hline
\end{tabular}

Vaisala in South America, Australia, and Europe. The mean biases at night for the two sonde types with the largest warm bias at daytime (AVK and VIZ-B2) are equal to -0.06 and $-0.42 \mathrm{~K}$, respectively (Table 2). The scatter of $\Delta T$ is similar for all sonde types during the day and night with standard deviations between 1.50 and $1.71 \mathrm{~K}$ (Table 2).

The global mean $\Delta T$ for the Vaisala RS92 of $0.16 \mathrm{~K}$ during the comparison period is slightly larger than the temperature comparison between Vaisala RS92 and COSMIC in 2007 (Ho et al., 2010b) $(\sim 0.01 \mathrm{~K})$ and in He et al. (2009) $(\sim 0.04 \mathrm{~K}$ from $\sim 200$ to $50 \mathrm{hPa})$. This could be in part because more RS92-RO pairs from lower SZA regions (for example, from the Southern Hemisphere and near-tropics; see Sect. 3.2) are included after 2007 (see Sect. 4).

\subsection{SZA-dependent temperature biases for Vaisala sondes}

More than $50 \%$ of RAOB data are from Vaisala sondes, from a number of different countries. In total, 267597 RS92 (ID $=79,80,81$ ) ensemble pairs are distributed in all latitudinal zones during the daytime. To quantify a possible residual radiation correction error for Vaisala RS92 measurements in the lower stratosphere, which may vary with SZA, we compare the mean temperature differences from 200 to
$20 \mathrm{hPa}$ for daytime and nighttime over different regions in Figs. 3 and 4, respectively.

Figure 3 indicates that RS92 measurements in different regions have a similar quality in terms of mean differences from RO with a small warm bias above $100 \mathrm{hPa}$, as well as similar standard deviations relative to the mean biases of approximately $1.5 \mathrm{~K}$. Because some stations in the United States are only interested in the tropospheric profiles and use smaller balloons, fewer RS92-RO samples are available above $70 \mathrm{hPa}$ compared to those in other countries.

Figure 4 depicts the mean RS92-RO temperature differences from 200 to $20 \mathrm{hPa}$ for nighttime. The nighttime RS92 data over different regions show similar standard deviations of about $1.5 \mathrm{~K}$ compared to those at daytime. In most of the regions, the mean nighttime temperature biases are similar to those in the daytime results, with small $(0.1-0.2 \mathrm{~K})$ warm biases above $100 \mathrm{hPa}$. These residual nighttime warm biases are not seen in the RAOB-RO ensemble pairs for Sippican MARK, VIZ-B2, AVK, and Shanghai sondes (see Sect. 3.3). This $0.1-0.2 \mathrm{~K}$ warm bias for RS92 at night could be due to calibration of the RS92 temperature sensor (see Dirksen et al., 2014).

Because the quality of RO temperature is not affected by sunlight, the small but obvious geographic-dependent biases 

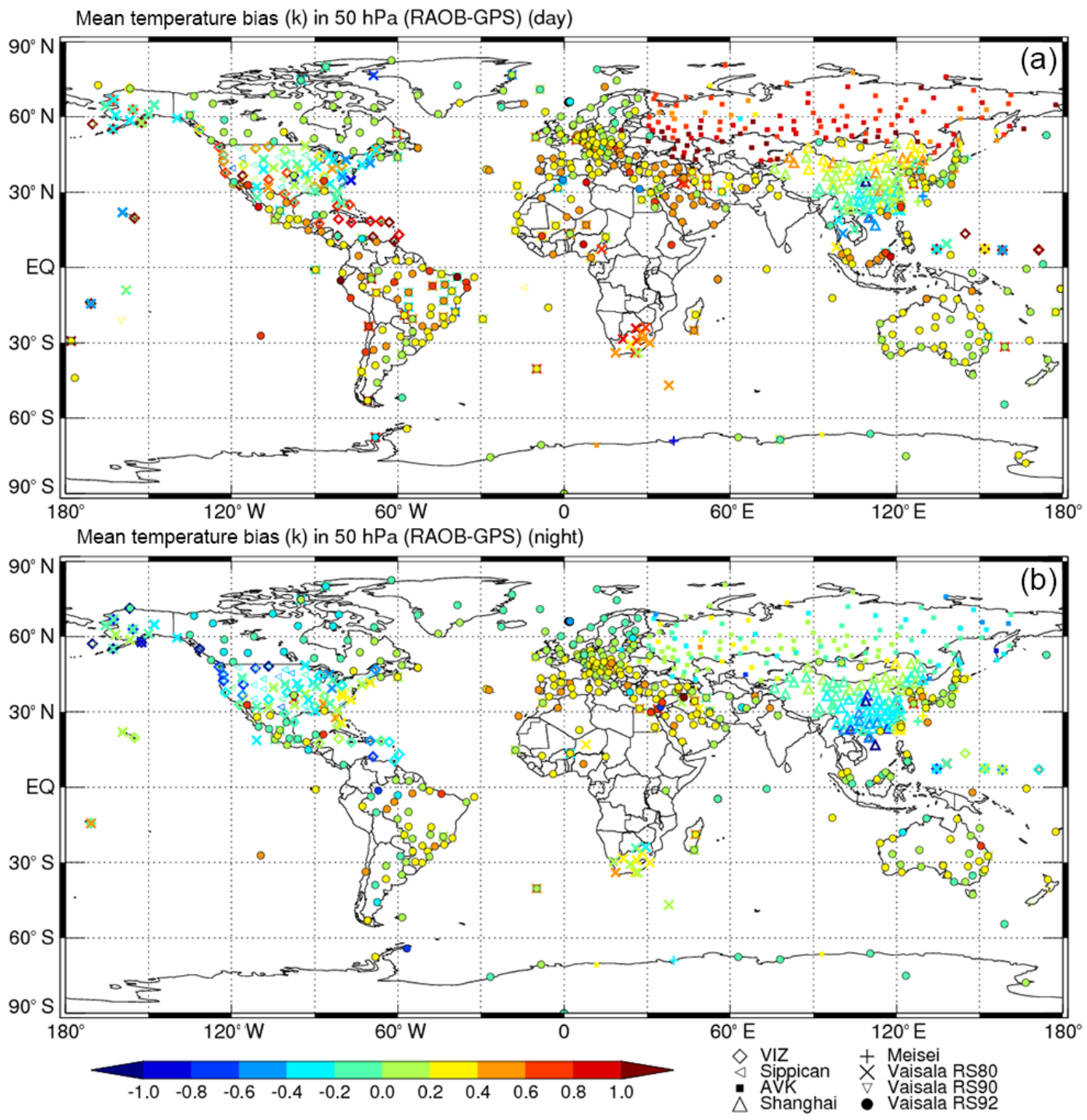

Figure 2. Mean RAOB-RO temperature biases at $50 \mathrm{hPa}$ for the RAOB-RO ensembles from June 2006 to April 2014 for (a) daytime, and (b) nighttime. Only those stations containing more than $50 \mathrm{RAOB}-\mathrm{RO}$ pairs are plotted.

are most likely due to the residual radiation correction for RS92 and when and how different countries apply the radiation correction (see Sect. 4.1).

To consider a possible SZA dependence of the temperature bias due to residual radiation errors for Vaisala RS92, we bin the computed temperature differences in $5^{\circ}$ bins at each of the RAOB mandatory pressure levels above $200 \mathrm{hPa}$ using all the RAOB-RO ensembles. Figure 5 depicts the temperature biases at $50 \mathrm{hPa}$ as function of $\mathrm{SZA}$ in six regions. Only those bins that contain more than 50 RAOB-RO pairs are included. Zero SZA is at noon and $90^{\circ} \mathrm{SZA}$ corresponds to sunrise or sunset. Figure 5 shows that the daily mean difference varies from $0.09 \mathrm{~K}$ (Canada) to $0.31 \mathrm{~K}$ (Brazil), with a slightly larger warm bias for low SZA (near noon) than that at higher SZA (late afternoon and in the night).

\subsection{Temperature biases for Sippican MARK, VIZ-B2, AVK-MRZ, and Shanghai sondes}

Unlike Vaisala sondes, which are distributed in almost all latitudinal zones, other sonde types are distributed mainly in the northern midlatitudes. Figure 6 depicts the mean temperature differences from 200 to $20 \mathrm{hPa}$ in the daytime for Sippican, VIZ-B2, AVK, and Shanghai. The biases for VIZ-B2 and AVK-MRZ are positive everywhere above $200 \mathrm{hPa}$, with means of about $0.7 \mathrm{~K}$. The biases are smaller for Sippican and Shanghai. These mean biases are similar to those from $\mathrm{He}$ et al. (2009). The small differences between these and $\mathrm{He}$ et al. (2009) results are likely due to the sampling differences between He et al. (2009) (August 2006 to February 2007, or 7 months) and this study (95 months). 

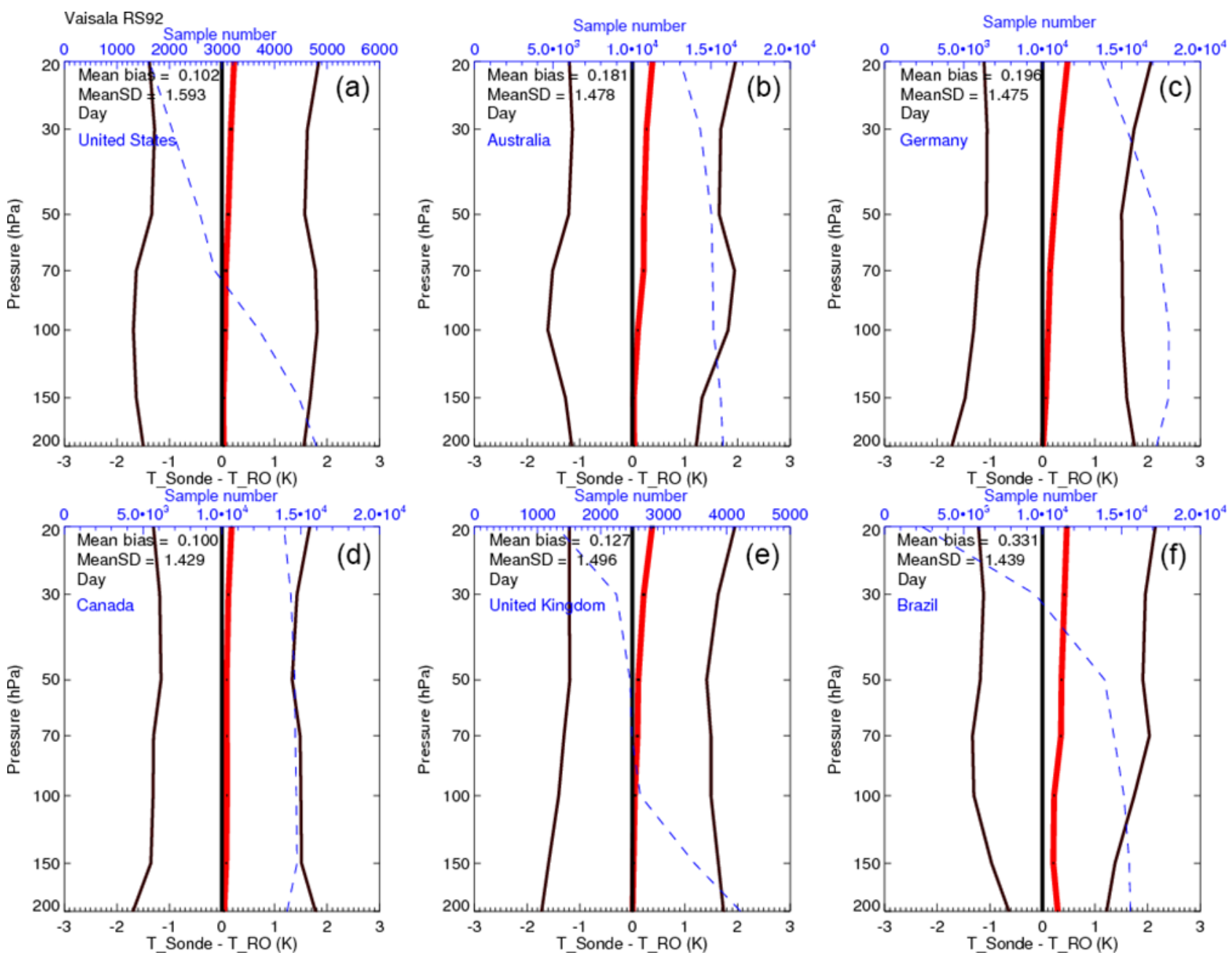

Figure 3. Comparisons of temperature between RS92 and RO for daytime over (a) United States, (b) Australia, (c) Germany, (d) Canada, (e) United Kingdom, and (f) Brazil. The red line is the mean difference; the black line is the standard deviation of the mean difference; the dotted line is the sample number. The top $x$ axis shows the sample number. The same symbols are also used for the following plots. We also plot the standard error of the mean (black dot) superimposed on the mean. The value of the standard error of the mean is less than $0.03 \mathrm{~K}$ depending on the sample numbers.

Figure 7 depicts the mean temperature differences from 200 to $20 \mathrm{hPa}$ in the nighttime also for Sippican, VIZ-B2, AVK-MRZ, and Shanghai. The nighttime biases are generally less than $0.1 \mathrm{~K}$ except from VIZ-B2 above $100 \mathrm{hPA}$ where they exceed $0.5 \mathrm{~K}$. The small positive values for VIZB2 and AVK-MRZ, which were present in the daytime (Fig. 6), are not present during the night (Fig. 7)

We also bin the temperature differences for these four sonde types in $5^{\circ}$ SZA bins for each mandatory pressure levels above $200 \mathrm{hPa}$ using all the RAOB-RO pairs from June 2006 to April 2014. Only those bins contain more than 50 RAOB-RO pairs are included. Figure 8 depicts the differences at $50 \mathrm{hPa}$ as a function of SZA for Sippican MARK, VIZ-B2, AVK-MRZ, and Shanghai.

The VIZ-B2 sonde has a large warm bias (as high as $2.0 \mathrm{~K}$ ) during daytime and a cold bias (as low as $-1.0 \mathrm{~K}$ ) at night.
AVK has a bias from about 0.7 to $1.1 \mathrm{~K}$ in the daytime where its nighttime biases are close to zero. The mean biases for the Sippican and Shanghai sondes show less diurnal variation and are 0.08 and $-0.17 \mathrm{~K}$, respectively.

\section{Comparison of the seasonal RAOB temperature biases in different regions}

Since there is some residual radiation error, we characterize the long-term stability of RAOB temperature measurements for different RAOB sensor types by quantifying their seasonal temperature biases relative to those of co-located RO data. 

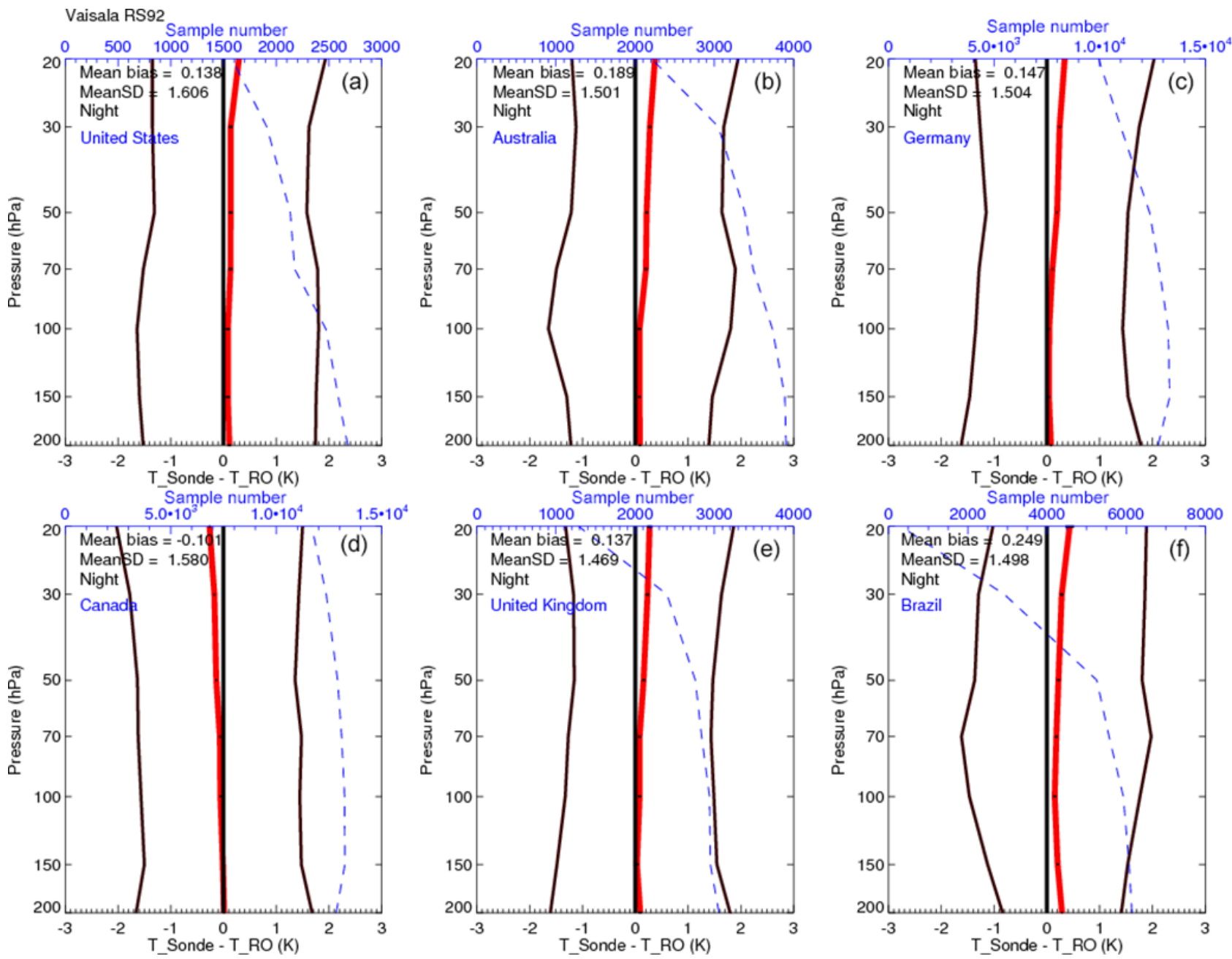

Figure 4. Comparisons of temperature between RS92 and RO for nighttime over (a) United States, (b) Australia, (c) Germany, (d) Canada, (e) United Kingdom, and (f) Brazil.

\subsection{Identification of RS92 temperature biases due to change of radiation correction}

The Vaisala RS92 radiosonde was introduced in 2003 and is scheduled to be replaced by the Vaisala RS41 in 2017. Vaisala included a reinforcement of the RS92 sensor in 2007, which affected the radiation error. To account for this sensor update, the radiation correction tables were updated in 2011 (RSN2010, software version 3.64), which is used to replace the original radiation correction table. Between 200 and $20 \mathrm{hPa}$, the correction in RSN2010 is about $0.1 \mathrm{~K}$ larger than in RSN2005 (see http://www. vaisala.com/en/products/soundingsystemsandradiosondes/ soundingdatacontinuity/RS92DataContinuity/Pages/ revisedsolarradiationcorrectiontableRSN2010.aspx).

It is likely that each country updated the correction table for their entire network. However, when exactly each country implemented these updated tables is unknown.
To identify possible RS92 temperature biases due to changes of the radiation correction table (i.e., RSN2010), we compare the mean $\Delta T$ from January 2007 to December 2010 to those from January 2011 to April 2014 over the United States, Australia, Germany, Canada, United Kingdom, and Brazil (Fig. 9a-f). There is no consistent pattern of differences in these two periods over the six regions, with mean differences ranging from $-0.122 \mathrm{~K}$ (Australia) to $0.047 \mathrm{~K}$ (United States). The small differences in profile shapes and magnitudes are an indication of the magnitude of the uncertainty in RS92 temperatures due to differences in implementing the radiation correction tables.

The Deutscher Wetterdienst (DWD), Germany's Meteorological Service, implemented the updated radiation correction for the Vaisala RS92 in the spring of 2015 rather than in 2011 to avoid inconsistencies with corrections already implemented in their data assimilation system. This may in part explain the greater consistency of $\Delta T$ over Germany for these two time periods than over other countries. This also in- 

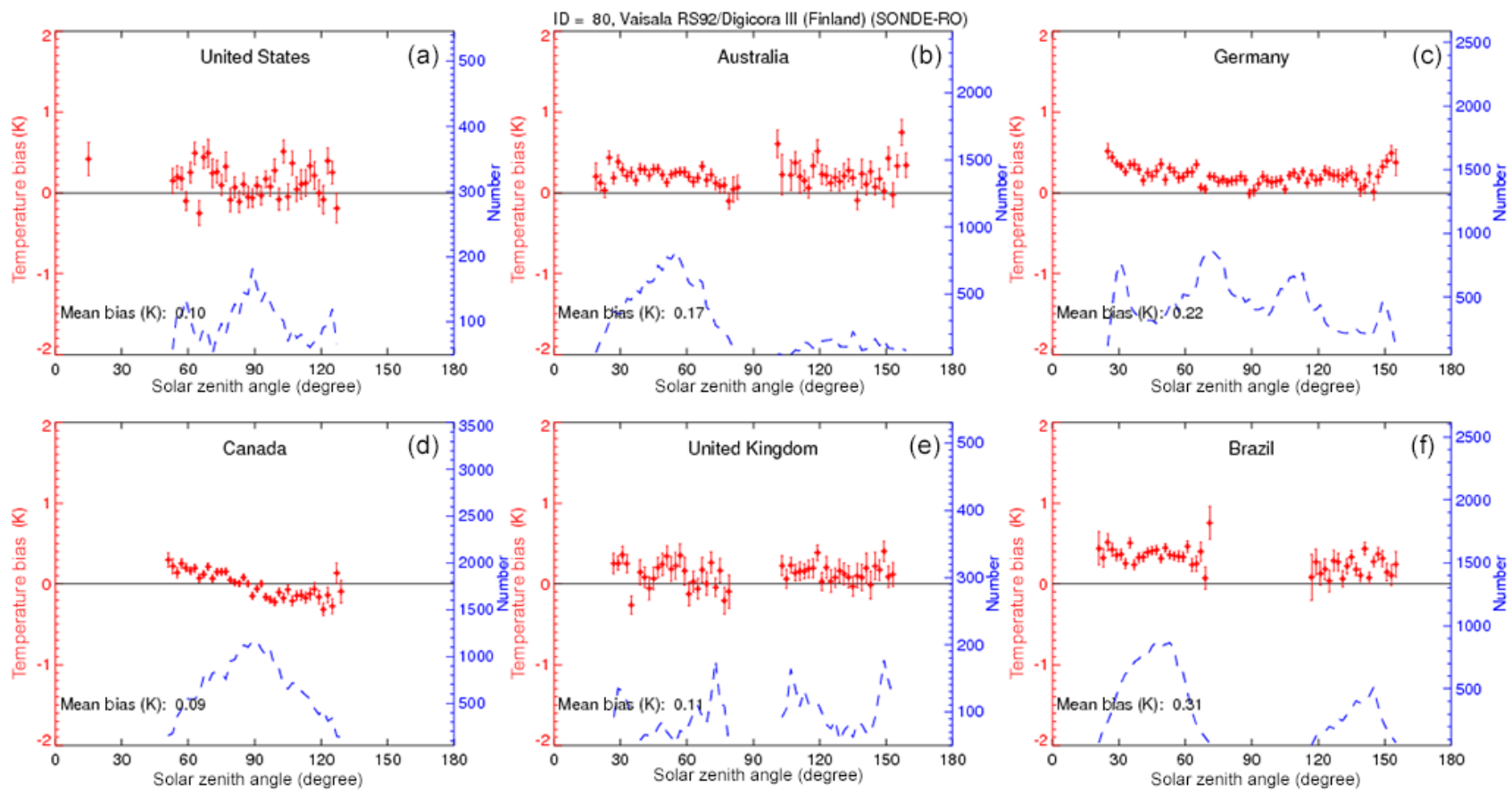

Figure 5. The mean temperature biases (RS92 minus RO) at $50 \mathrm{hPa}$ varying for SZA from 0 degrees to 180 degrees for (a) United States, (b) Australia, (c) Germany, (d) Canada, (e) United Kingdom, and (f) Brazil. The red cross is the mean difference for each 5 SZA bins; the red vertical line is the standard deviation of error defined as standard deviation divided by sample numbers; the vertical red lines superimposed on the mean are the standard error of the mean; the black line indicates zero mean; the blue dash line is the sample number. The right $y$ axis shows the sample number. Only bins for more than 50 RAOB-RO pairs are plotted.

dicates the importance of establishing traceability through careful documentation and metadata tracking, which is especially important for using radiosonde data in climate studies. The relatively small temperature difference between these two periods over the United States is most likely a statistical artifact due to the very small number of coincidences in this period.

\subsection{Time series and trends of de-seasonalized radiosonde-RO differences}

In this section we look at time series and trends in the deseasonalized radiosonde-RO temperature differences from 2006 to 2014 in order to determine the long-term stability of these differences. Ideally, if both radiosondes and RO were free of biases, the time series would be stable and show small differences near zero with small standard deviations and no trends. We choose $50 \mathrm{hPa}$ for showing these time series because the biases tend to be larger at this level than at lower levels. We also computed time series for $150 \mathrm{hPa}$, but except for lower biases the results were similar to those at $50 \mathrm{hPa}$ (not shown).

Figure 10 shows daytime and nighttime time series of monthly mean temperature biases at $50 \mathrm{hPa}$ for Vaisala RS92 for the United States, Australia, Germany, Canada, United Kingdom, and Brazil. Table 3 summarized the mean and standard deviation of the monthly mean temperature differences for RS92 and RO at $50 \mathrm{hPa}$. Figure 10 indicates that there is little variation over time in the monthly mean temperature differences at $50 \mathrm{hPa}$ in all six regions, with little difference between day and night values. The magnitudes of the mean biases range from $-0.01 \mathrm{~K}$ for Canada to over $0.2 \mathrm{~K}$ in Australia, Germany, and Brazil. The standard deviations range from a low of $0.18 \mathrm{~K}$ (Australia, day) to a high of $0.46 \mathrm{~K}$ (United States, night). The small (less than $0.5 \mathrm{~K}$ ) standard deviation for RS92 over daytime and nighttime over these six regions demonstrates the long-term stability of RS92 data.

Figure 11 shows the daytime and nighttime time series of monthly mean temperature biases for Sippican MARK IIA, VIZ-B2, AVK-MRZ, and Shanghai in northern hemispheric midlatitude $\left(60-20^{\circ} \mathrm{N}\right)$ at $50 \mathrm{hPa}$ and the results are summarized in Table 4 . All daytime biases are below $0.25 \mathrm{~K}$ in magnitude, except for Russia $(0.8 \mathrm{~K})$ and VIS-B2 $(0.87 \mathrm{~K})$. The magnitudes of the mean nighttime biases are all less than $0.25 \mathrm{~K}$ except for VIS-B2, which is $-0.56 \mathrm{~K}$. The daytime biases for Russia and VIS-B2 contain obvious inter-seasonal variation.

Figure 12 shows daytime and nighttime time series of monthly mean de-seasonalized temperature biases at $50 \mathrm{hPa}$ for Vaisala RS92 for the United States, Australia, Germany, Canada, United Kingdom, and Brazil. Table 3 summarizes 

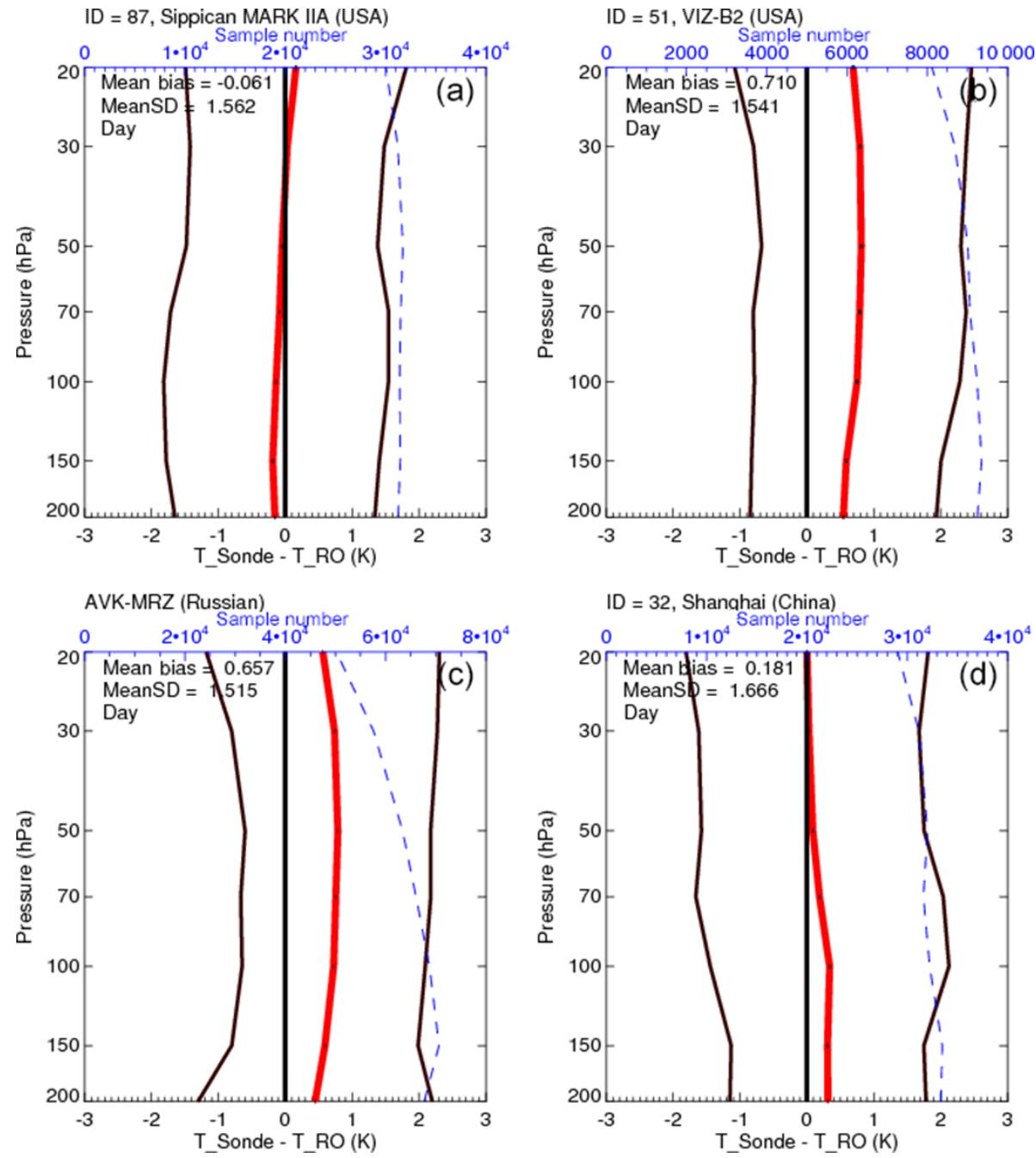

Figure 6. Comparisons of temperature between radiosonde and RO during the daytime for (a) Sippican over United States minus RO, (b) VIZ-B2 over United States minus RO, (c) Russian sonde minus RO, (d) Shanghai minus RO.

Table 3. Mean, standard deviation (SD) of monthly temperature differences (K), de-seasonalized trend of temperature differences (K/5 yr), and root mean square (RMS) of de-seasonalized RS92-RO temperature difference time series at $50 \mathrm{hPa}$ over United States, Australia, Germany, Canada, United Kingdom, and Brazil.

\begin{tabular}{|c|c|c|c|c|c|c|c|c|c|c|c|c|}
\hline & \multicolumn{2}{|c|}{ United States } & \multicolumn{2}{|c|}{ Australia } & \multicolumn{2}{|c|}{ Germany } & \multicolumn{2}{|c|}{ Canada } & \multicolumn{2}{|c|}{ United Kingdom } & \multicolumn{2}{|c|}{ Brazil } \\
\hline & Day & Night & Day & Night & Day & Night & Day & Night & Day & Night & Day & Night \\
\hline mean bias & 0.08 & 0.19 & 0.22 & 0.23 & 0.22 & 0.21 & -0.06 & -0.01 & 0.12 & 0.16 & 0.35 & 0.26 \\
\hline SD of mean bias & 0.4 & 0.46 & 0.18 & 0.3 & 0.2 & 0.24 & 0.35 & 0.32 & 0.39 & 0.42 & 0.22 & 0.43 \\
\hline $\begin{array}{l}\text { De-seasonalized } \\
\text { Trend of Differences } \\
(\mathrm{K} / 5 \mathrm{yr})\end{array}$ & 0.001 & -0.211 & 0.167 & -0.083 & -0.016 & -0.135 & 0.232 & -0.018 & 0.264 & -0.163 & 0.118 & -0.104 \\
\hline $\begin{array}{l}\text { De-seasonalized } \\
\text { Trend of RO } \\
\text { Temperature }(\mathrm{K} / 5 \mathrm{yr})\end{array}$ & 0.941 & 0.506 & -0.26 & 0.082 & 0.29 & 0.708 & -0.69 & -0.534 & 0.509 & 1.143 & -0.076 & -0.354 \\
\hline $\begin{array}{l}\text { RMS of } \\
\text { de-seasonalized } \\
\text { difference }\end{array}$ & 0.365 & 0.439 & 0.161 & 0.275 & 0.173 & 0.22 & 0.276 & 0.215 & 0.358 & 0.392 & 0.212 & 0.398 \\
\hline
\end{tabular}



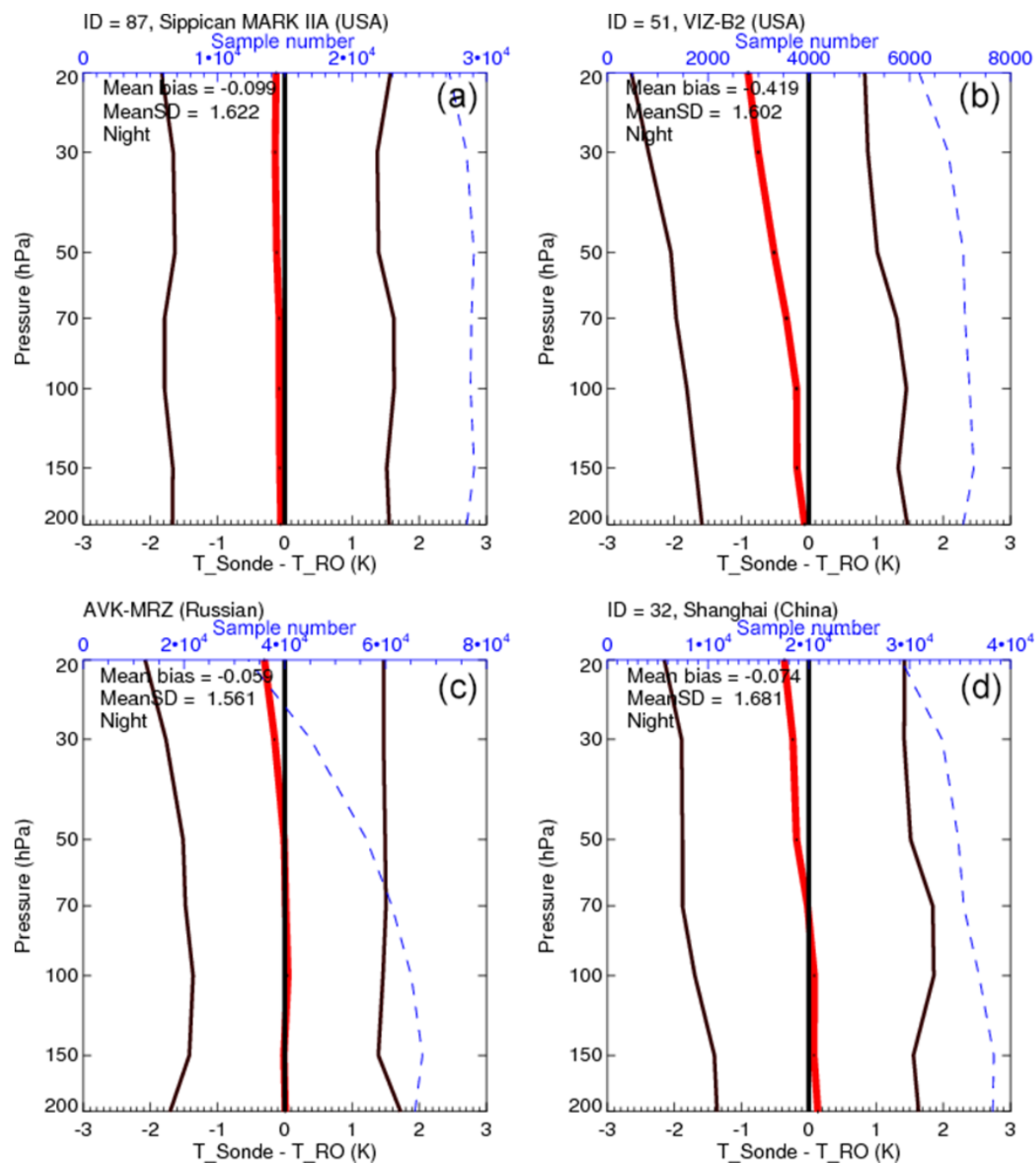

Figure 7. Comparisons of temperature between radiosonde and RO during the nighttime for (a) Sippican over United States minus RO, (b) VIZ-B2 over United States minus RO, (c) Russian sonde minus RO, and (d) Shanghai minus RO.

the trends of the de-seasonalized temperature differences, and shows the de-seasonalized trends in RO temperatures for comparison. The root mean square (RMS) of the deseasonalized time series (RMS of difference) in Table 3 indicates the trend uncertainty of the time series.

The de-seasonalized temperature differences are computed from

$\Delta T^{\text {Deseason }}(l, m, k)=T_{\mathrm{RAOB}}(l, m, k)-\overline{T^{\text {Time }}}\left(l, m, k^{\prime}\right)$,

where $l, m$, and $k$ are the indices of the month bin for each layer, zone, and month for the whole time series $(k=1$ to 95), respectively, and $k^{\prime}$ is the index of the month bin of the year $(k=1$ to 12$) . \overline{T^{\text {Time }}}\left(l, m, k^{\prime}\right)$ is the mean RO temperature co-located for different sensor types for each level $(l)$, zone $(m)$, and averaged over all available years for a particular month $\left(k^{\prime}\right)$. Note that because the period of available measurements for each of the sensor types is different, the months used to compute $T^{\text {Time }}\left(l, m, k^{\prime}\right)$ may vary for different sensor types.

Figure 12 indicates the de-seasonalized trends in daytime temperature differences for RS92 are within \pm 0.26 $(\mathrm{K} / 5 \mathrm{yr})$. The greatest magnitudes of the trends are 0.23 and $0.26 \mathrm{~K} / 5 \mathrm{yr}$ over Canada and United Kingdom, respectively. These larger de-seasonalized trends may be a result of incomplete daytime radiation corrections applied in these regions in 2007-2010 and 2011-2014 (Fig. 9). The largest nighttime de-seasonalized trend is in the United States $(-0.21 \mathrm{~K} / 5 \mathrm{yr})$.

The de-seasonalized trends in $\mathrm{RO}$ temperatures are generally larger than those for the radiosonde-RO differences (Table 3). A maximum de-seasonalized trend of $1.14 \mathrm{~K} / 5 \mathrm{yr}$ is found for nighttime temperatures over the United Kingdom. A minimum de-seasonalized trend of $-0.69 \mathrm{~K} / 5 \mathrm{yr}$ is found for daytime temperatures over Canada. Trends with magnitude greater than $0.5 \mathrm{~K} / 5 \mathrm{yr}$ are found over the United States, Germany, Canada, and the United Kingdom. The 

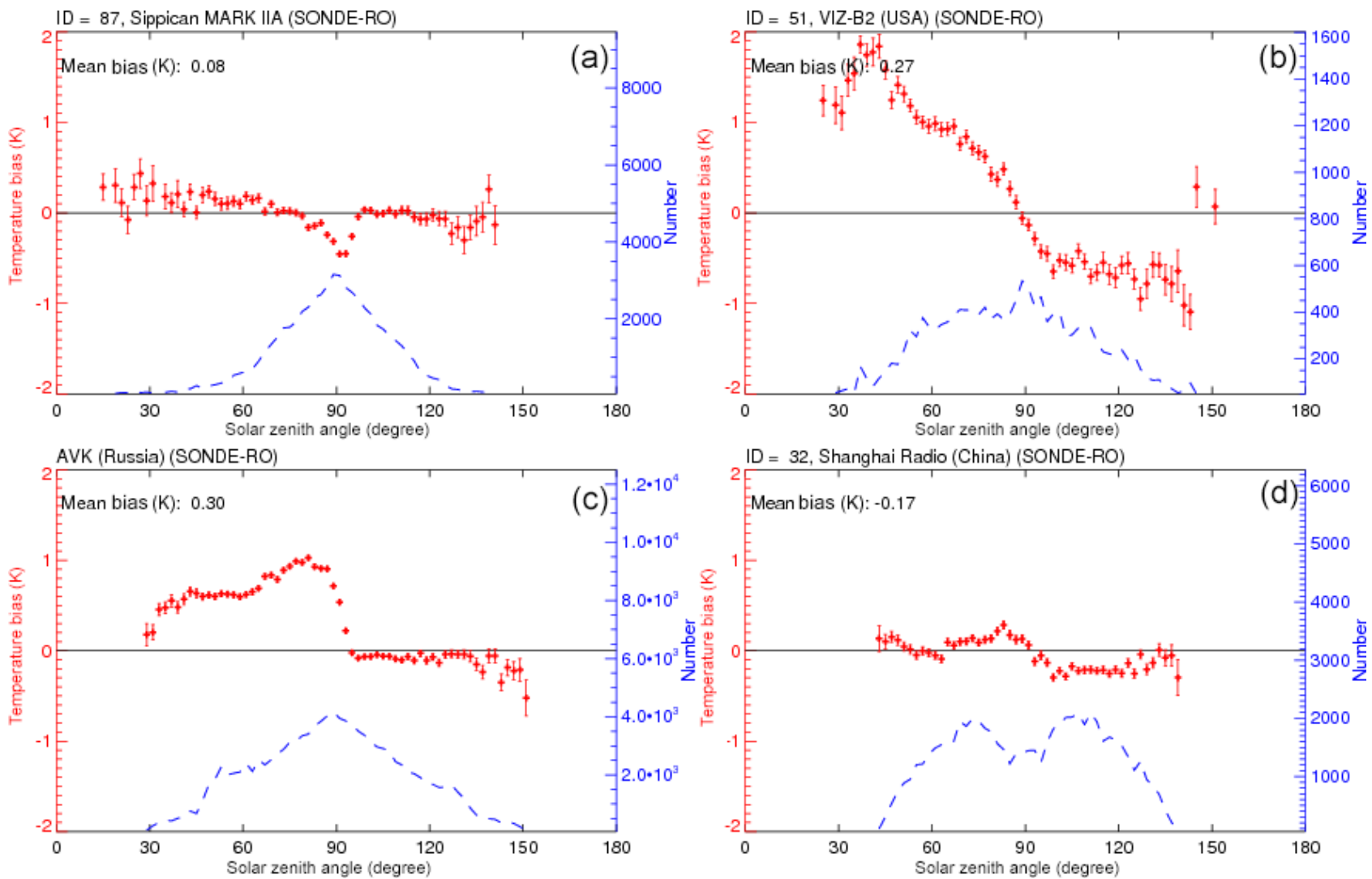

Figure 8. The mean temperature biases at $50 \mathrm{hPa}$ varying for SZA from 0 to $180^{\circ}$ for (a) Sippican over United States minus RO, (b) VIZ-B2 over United States minus RO, (c) Russian sonde minus RO, and (d) Shanghai minus RO. Only bins for more than 50 RAOB-RO pairs are plotted.

Table 4. Mean, standard deviation (SD), de-seasonalized trend of temperature differences (K/5 yr), and root mean square (RMS) of deseasonalized time series of RAOB minus RO temperature difference at $50 \mathrm{hPa}$ for global Vaisala (RS80, RS90, and RS92), and other sensor types in the northern hemispheric midlatitude $\left(60-20^{\circ} \mathrm{N}\right)$. The $95 \%$ confidence intervals for trend of differences are listed in the parentheses.

\begin{tabular}{|c|c|c|c|c|c|c|c|c|c|}
\hline & \multirow[t]{2}{*}{ ID } & \multicolumn{4}{|c|}{ Day } & \multicolumn{4}{|c|}{ Night } \\
\hline & & $\begin{array}{r}\text { Mean } \\
\text { bias }\end{array}$ & $\begin{array}{r}\text { SD of } \\
\text { MB }\end{array}$ & $\begin{array}{r}\text { De-seasonalized trend of } \\
\text { difference }(\mathrm{K} / 5 \mathrm{yr})\end{array}$ & $\begin{array}{r}\text { RMS of } \\
\text { difference }\end{array}$ & $\begin{array}{r}\text { Mean } \\
\text { bias }\end{array}$ & $\begin{array}{r}\text { SD of } \\
\text { MB }\end{array}$ & $\begin{array}{r}\text { De-seasonalized trend of } \\
\text { difference }(\mathrm{K} / 5 \mathrm{yr})\end{array}$ & $\begin{array}{r}\text { RMS of } \\
\text { difference }\end{array}$ \\
\hline RS80 & $\begin{array}{l}37,52 \\
61,67\end{array}$ & 0.18 & 0.29 & $0.187(0.073,0.301)$ & 0.268 & 0.13 & 0.33 & $0.114(-0.019,0.248)$ & 0.301 \\
\hline RS90 & 71 & 0.16 & 0.29 & $-0.006(-0.123,0.111)$ & 0.26 & 0.17 & 0.38 & $0.043(-0.115,0.201)$ & 0.352 \\
\hline RS92 & $\begin{array}{l}79,80 \\
81\end{array}$ & 0.22 & 0.07 & $0.074(0.051,0.097)$ & 0.062 & 0.12 & 0.12 & $-0.094(-0.131,-0.057)$ & 0.093 \\
\hline Russia & $\begin{array}{ll}27, & 75, \\
88, & 89 \\
58 & \end{array}$ & 0.8 & 0.22 & $-0.137(-0.205,-0.068)$ & 0.164 & -0.03 & 0.21 & $-0.143(-0.218,-0.067)$ & 0.18 \\
\hline VIZ-B2 & 51 & 0.87 & 0.37 & $0.468(0.358,0.579)$ & 0.322 & -0.56 & 0.43 & $-0.348(-0.518,-0.177)$ & 0.386 \\
\hline $\begin{array}{l}\text { Sippican } \\
\text { MARKIIA } \\
\text { Chip }\end{array}$ & 87 & -0.12 & 0.33 & $0.405(0.304,0.507)$ & 0.292 & -0.12 & 0.21 & $0.244(0.168,0.320)$ & 0.197 \\
\hline Shanghai & 32 & 0.1 & 0.18 & $0.179(0.081,0.276)$ & 0.161 & -0.2 & 0.17 & $-0.015(-0.120,0.090)$ & 0.159 \\
\hline $\begin{array}{l}\text { Meisei } \\
\text { Japan }\end{array}$ & 47 & 0.07 & 0.69 & $0.006(-0.353,0.365)$ & 0.619 & 0.05 & 0.51 & $-0.086(-0.369,0.197)$ & 0.494 \\
\hline
\end{tabular}

fact that these de-seasonalized trends in RO are significantly greater than the de-seasonalized trends in the differences suggests that they represent a physical signal in these regions.
However, the time series is too short to represent a longterm climate signal; instead these likely represent real but short-term trends associated with natural variability. A long- 
Vaisala RS92, (20060601 20101231 - 20110101 20140430)
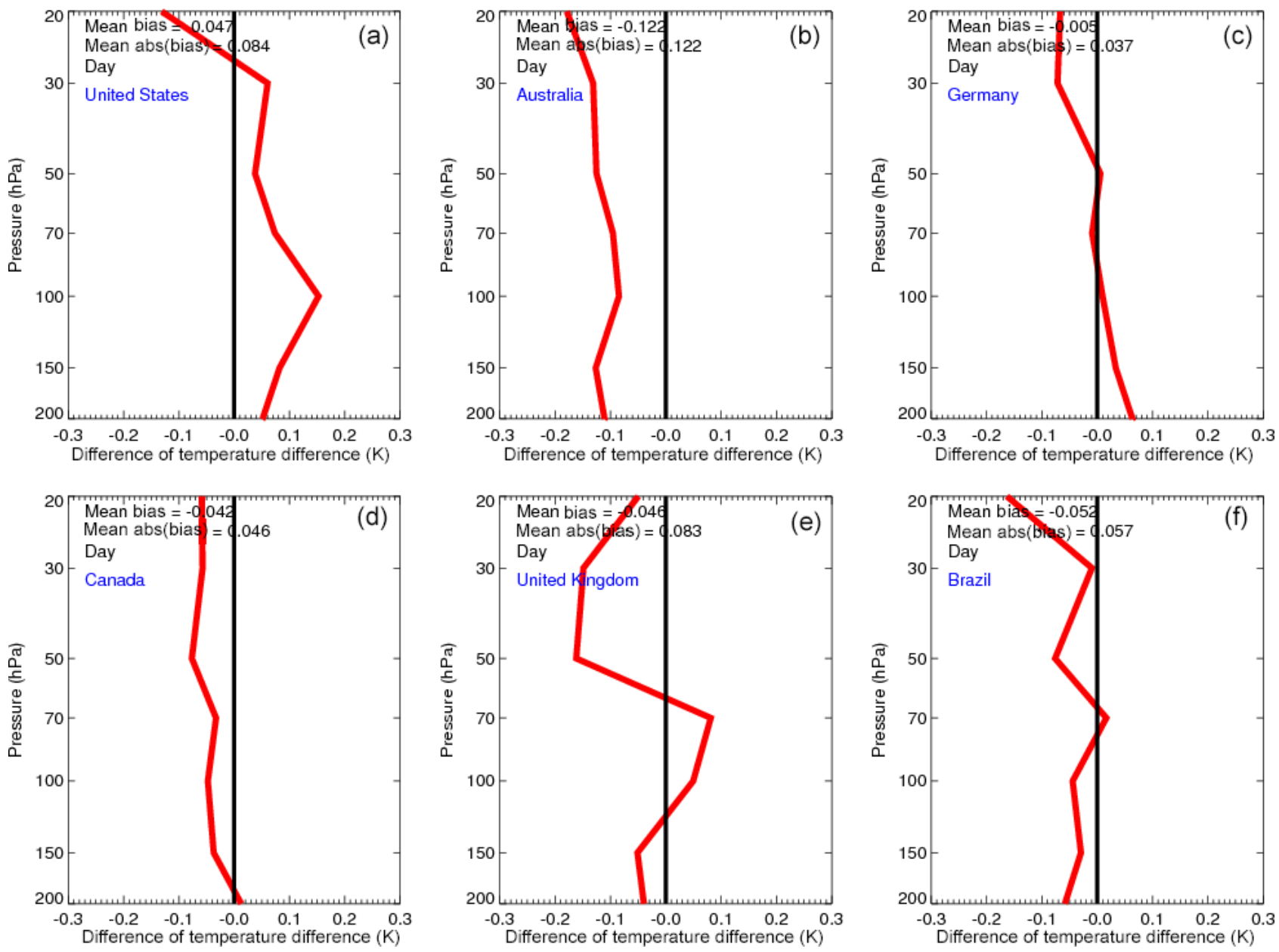

Figure 9. The temperature differences between RS92 - RO from January 2007 to December $2010\left(\Delta T\left(\mathrm{RS} 92_{200701-201012))}\right.\right.$ and those from January 2011 to April 2014 ( $\Delta T(\mathrm{RS} 92201$ 101-201404)) over (a) United States, (b) Australia, (c) Germany, (d) Canada, (e) United Kingdom, and (f) Brazil.

term (de-seasonalized) trend in temperature at this level associated with global warming (stratospheric cooling) might be approximately -0.1 to $-0.2 \mathrm{Kdecade}^{-1}$ or -0.05 to $-0.1 \mathrm{~K} / 5 \mathrm{yr}$ (Randel et al., 2016). Trends of the RS-92 minus RO differences reported in this paper for the Vaisala RS92 radiosonde at $50 \mathrm{hPa}$ (Table 3) range from $-0.21 \mathrm{~K} / 5 \mathrm{yr}$ (US, night) to $0.26 \mathrm{~K} / 5 \mathrm{yr}$ (United Kingdom, day), which are comparable to those reported by Randel et al. (2016).

We compare the global trend of radiosonde-RO temperature differences for the Vaisala and other radiosondes at $50 \mathrm{hPa}$ in Table 4. The Vaisala RS92 biases are 0.22 (day) and $0.12 \mathrm{~K}$ (night). The trends in global de-seasonalized temperature differences for Vaisala RS92 for daytime and nighttime are equal to 0.07 and $-0.09 \mathrm{~K} / 5 \mathrm{yr}$, respectively. The $95 \%$ confidence intervals for slopes are shown in the parentheses in Table 4. This indicates that although there might be a small residual radiation error for RS92, the trend in RS92 and
RO temperature differences from June 2006 to April 2014 is within $\pm 0.09 \mathrm{~K} / 5 \mathrm{yr}$ globally. These values are just above the $1 \sigma$ calibration uncertainty estimated by Dirksen et al. (2014). This means that probably the stability of the calibration alone could explain most of this very small trend. It is also consistent with the change in radiation correction.

Figure 13 depicts the de-seasonalized temperature differences for Sippican MARK IIA, VIZ-B2, AVK-MRZ, and Shanghai in northern hemispheric midlatitude $\left(60-20^{\circ} \mathrm{N}\right)$ at $50 \mathrm{hPa}$ and the results are summarized in Table 4 . The $95 \%$ confidence intervals for slopes are shown in the parentheses in Table 4. The de-seasonalized trend of the daytime differences varies from -0.14 (Russia) to $0.47 \mathrm{~K} / 5 \mathrm{yr}$ (VIZ-B2). The magnitudes of the daytime trend of difference are less than $0.2 \mathrm{~K} / 5 \mathrm{yr}$ for all sensor types except for VIZ-B2 and Sippican, both of which exceed $0.4 \mathrm{~K} / 5 \mathrm{yr}$. These are much larger than those of the Vaisala RS92 $(0.07 \mathrm{~K} / 5 \mathrm{yr})$. 

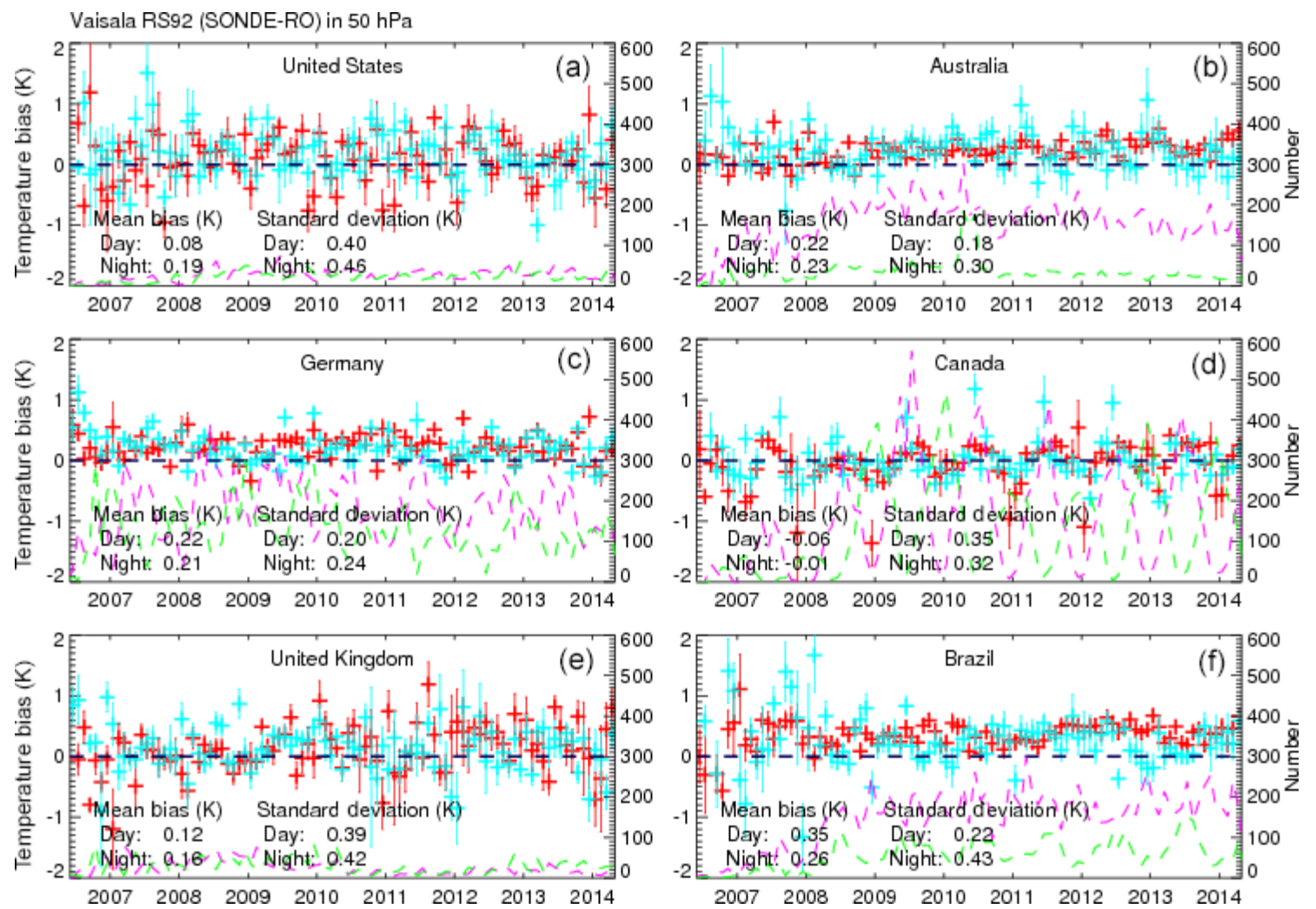

Figure 10. The time series of monthly mean temperature differences from RO at $50 \mathrm{hPa}$ for RS92 for (a) United States, (b) Australia, (c) Germany, (d) Canada, (e) United Kingdom, and (f) Brazil. The red cross is the mean difference for RS92 minus RO temperature at $50 \mathrm{hPa}$ during the daytime and the blue cross is for that during the nighttime; the vertical lines superimposed on the mean values are the standard error of the mean for daytime and nighttime; the black line indicates zero temperature bias; the pink/green dash line is the sample number for the daytime and nighttime, respectively. The right $y$ axis shows the sample number. The same symbols are also used for the following plots.
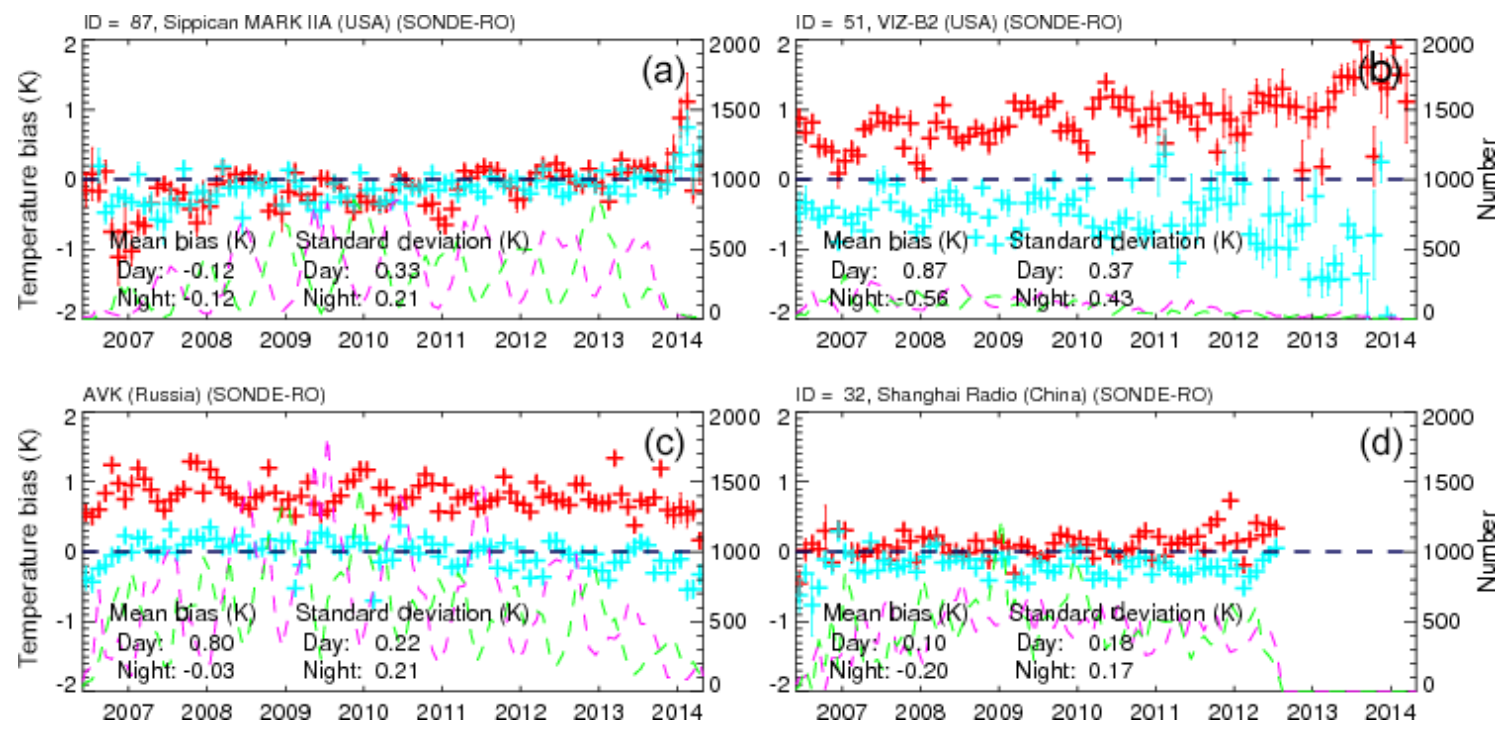

Figure 11. The time series of temperature difference at $50 \mathrm{hPa}$ for (a) Sippican over United States minus RO, (b) VIZ-B2 over United States minus RO, (c) Russian sonde minus RO, and (d) Shanghai minus RO in the northern hemispheric midlatitude $\left(60-20^{\circ} \mathrm{N}\right)$.

The corresponding nighttime de-seasonalized trends in the biases vary from -0.35 (VIZ-B2) to $0.24 \mathrm{~K} / 5 \mathrm{yr}$ (Sippican).
Again, these are much larger than those of Vaisala RS92 

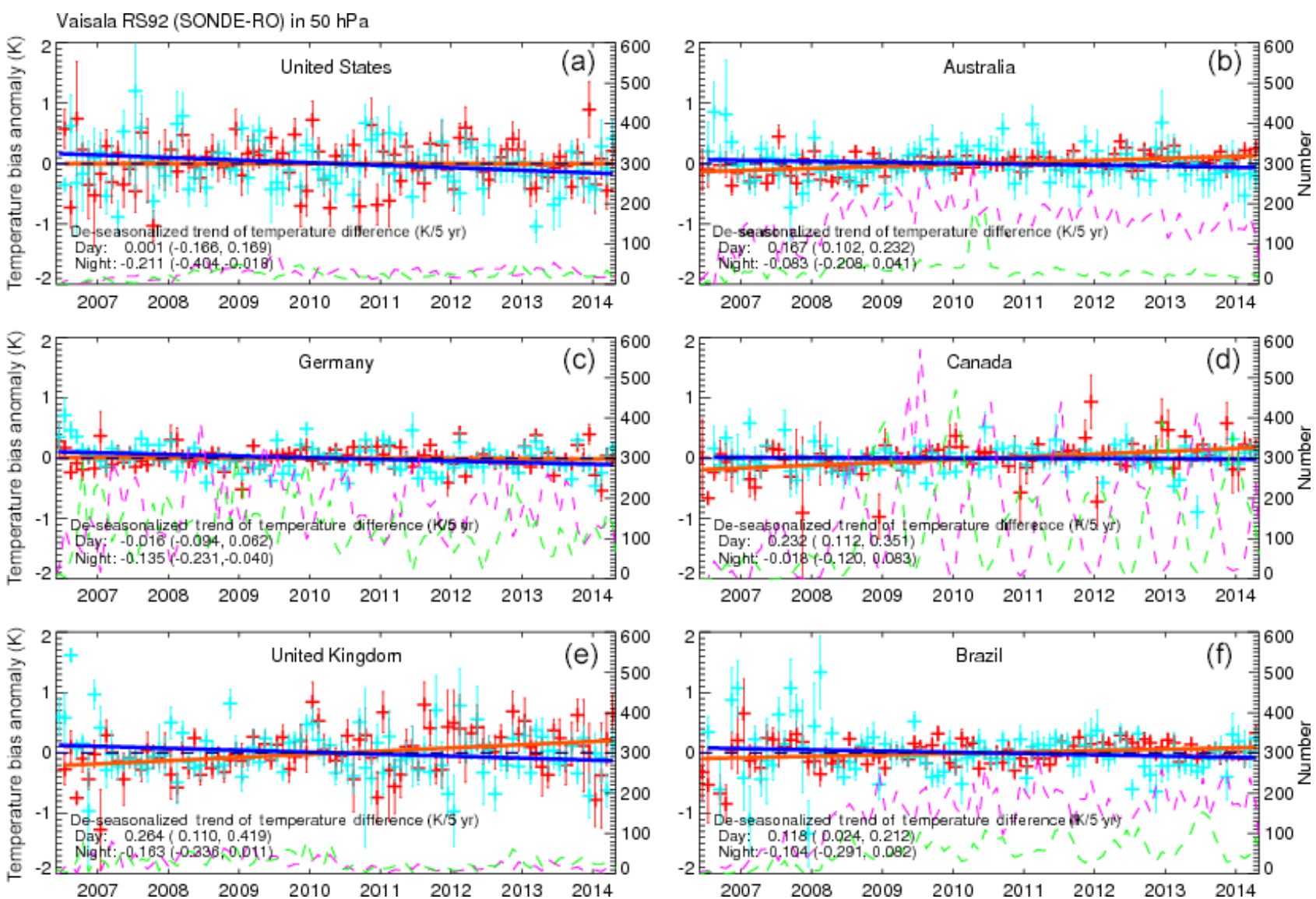

Figure 12. The time series of de-seasonalized temperature differences at $50 \mathrm{hPa}$ for RS92 for (a) United States, (b) Australia, (c) Germany, (d) Canada, (e) United Kingdom, and (f) Brazil. The red cross is the mean difference for RS92 minus RO temperature at $50 \mathrm{hPa}$ during the daytime and the blue cross is for that during the nighttime; the vertical lines superimposed on the mean values are the standard error of the mean for daytime and nighttime. The number of the monthly RAOB-RO pairs for daytime is indicated by the pink dashed line and that for nighttime by the green dashed line. The vertical lines superimposed on the monthly mean are the standard errors of the mean. Day and night trends are shown by solid red and blue lines, respectively. The zero difference is indicated by the dashed black line. The $95 \%$ confidence intervals for slopes are shown in the parentheses. The right $y$ axis shows the sample number. The same symbols are also used in Fig. 13 .

$(-0.09 \mathrm{~K} / 5 \mathrm{yr})$. Thus the VIZ-B2 sensor stands out as having larger biases and trends than do the other sensors.

\section{Conclusions}

In this study, we used consistently reprocessed GPS RO temperature data to characterize radiosonde temperature biases and the inter-seasonal and interannual variability of these biases in the upper troposphere and lower stratosphere for different radiosonde types. We reach the following conclusions.

1. SZA-dependent biases: the solar radiative effect on different sensors is the dominant error source of RAOB temperature biases during daytime. With the consistent precision of RO temperature data between COSMIC and Metop-A, we are able to identify the mean temperature biases from the 200 to $20 \mathrm{hPa}$ layer among older sensors (i.e., Vaisala RS80 sensors) and new sensors (i.e., RS92 sensors), as well as the daytime and nighttime biases for the same sensor types which are usually distributed in the same countries (i.e., Shanghai sensor in China, AVK in Russia, VIZ-B2 in United States). Because the quality of RO temperature is not affected by sunlight, those daytime/nighttime biases mainly originate from uncorrected radiation biases for each individual sensor types. Most of the sensor types contain positive temperature biases from 200 to $20 \mathrm{hPa}$. The mean temperature difference $(\mathrm{K})$ from the layer from 200 to $20 \mathrm{hPa}$ for Vaisala RS92 during the daytime is equal to $0.2 \mathrm{~K}$, which is statistically insignificant. The corresponding difference is equal to $0.71 \mathrm{~K}$ for VIZB2, 0.66 K for Russian AVK-MRZ, which is statistically significant. Most of the sensor types show a cold bias at night, where the VIZ-B2 bias is as large as $-0.42 \mathrm{~K}$. 

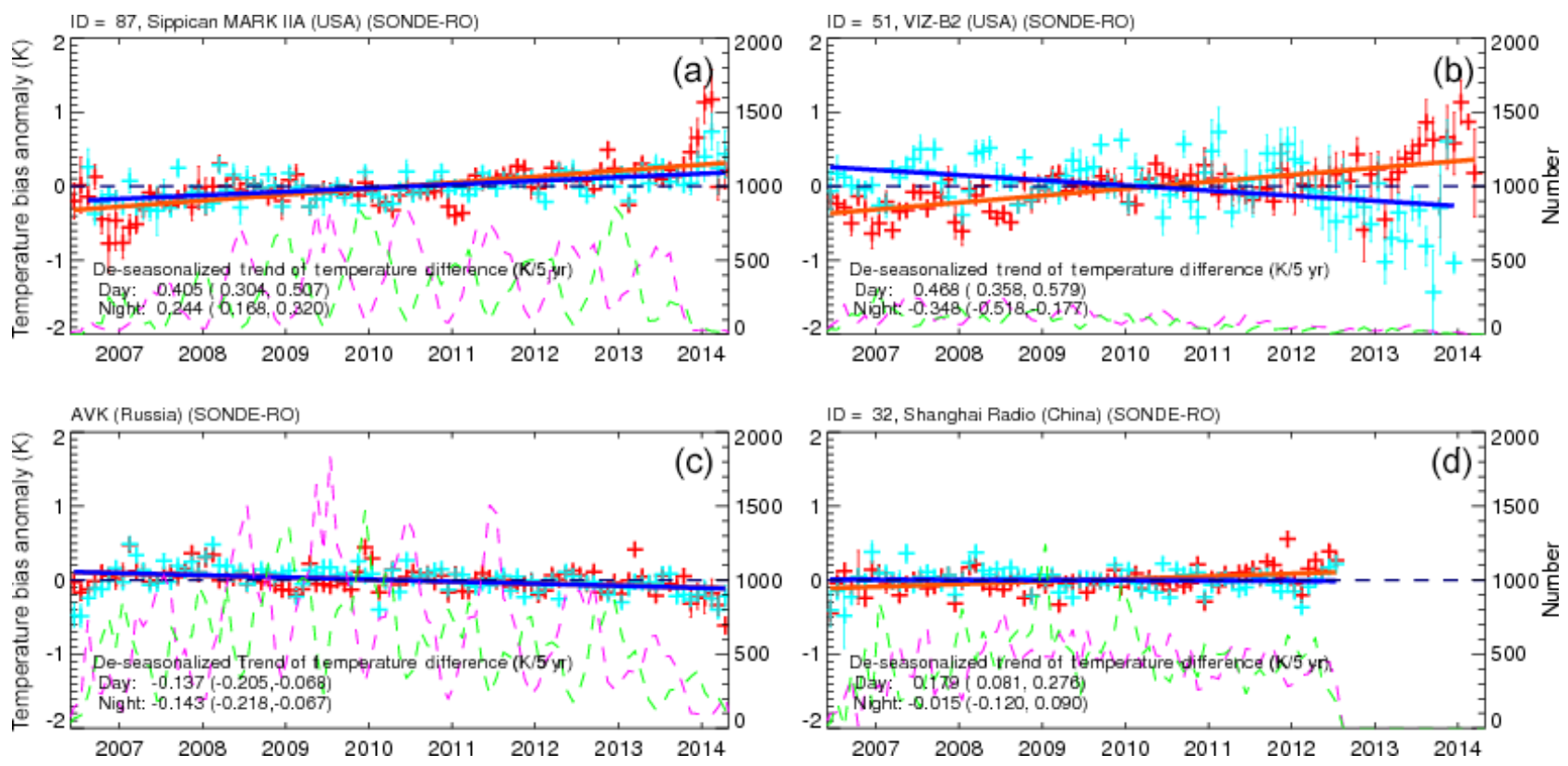

Figure 13. The time series of de-seasonalized temperature differences at $50 \mathrm{hPa}$ for (a) Sippican over United States minus RO, (b) VIZ-B2 over United States minus RO, (c) Russian sonde minus RO, and (d) Shanghai minus RO in the northern hemispheric midlatitude (60-20 N). The $95 \%$ confidence intervals for slopes are shown in the parentheses.

2. Residual SZA-dependent biases: after applying the solar radiation correction, most of the RS92 daytime biases are removed. However, a small residual radiation bias for RS92 remains, which varies with different geographical region or operating organization. Similar to the results of He et al. (2009) and Sun et al. (2010, 2013), we find that there exists a small SZA-dependent biases among different sensor types. The daily mean difference for RS92 varies from 0.09 (Canada) to $0.31 \mathrm{~K}$ (Brazil), with a slightly larger warm bias for low SZA (near noon) than that at higher SZA (late afternoon and in the night). These biases are less than the uncertainty described in Dirksen et al. (2014).

3. Changes of the radiation correction and RAOB temperature uncertainty due to when and how the radiative correction was implemented: the correction for RSN2010 is about $0.1 \mathrm{~K}$ higher than those from RSN2005. To identify the possible RS92 temperature biases due to changes of radiation correction table, we compared the mean RS92 temperature differences from January 2007 to December 2010 to those from January 2011 to April 2014. Results show that there is no consistent pattern of differences in these two periods over the six regions, with mean differences ranging from -0.122 (Australia) to $0.047 \mathrm{~K}$ (United States). Changing sensors independently of the appropriate radiation correction introduces extra uncertainties of the RS92 trends. The relatively small temperature difference between these two periods over the United States is most likely a statistical artifact due to the small number of coincidences in this period. The relatively small temperature difference between these two periods over the Germany may be because the DWD implemented the updated radiation correction for the Vaisala RS92 in the spring of 2015 rather than 2011 to avoid inconsistencies with corrections already implemented in their data assimilation system. This also indicates the importance of establishing traceability through careful documentation and metadata tracking, which is especially crucial for radiosonde data used in climate studies.

4. We used time series of RAOB-RO differences to indicate the long-term stability for each sonde type. The uncertainties are from the combined effects of (i) uncorrected SZA-dependent biases, (ii) change of radiation correction, (iii) when and how the radiation correction was implemented, and (iv) small samples used in the time series and trend analysis. Results show that the time series of the RS92 differences at all regions are, in general, stable in time with a small day-night difference in each region. Other sensors have much larger variation than those of Vaisala RS92.

5. We found that the variation of mean radiosonde-RO temperature differences in different regions is closely related to the corresponding variation of SZA, especially for VIZ-B2 and AVK-MRZ during the daytime. The Sippican MARK IIA over the United States and the Shanghai sondes do not show significant seasonal variation. The de-seasonalized trend in RS92 
and RO differences from June 2006 to April 2014 is within $\pm 0.09 \mathrm{~K} / 5 \mathrm{yr}$ globally (Table 4 ). The trend of deseasonalized daytime temperature differences for Sippican, VIZ-B2, Russia AVK, and Shanghai are much larger than those of RS92. Overall, the Vaisala RS92 radiosondes show a quality and stability that make them suitable for use in long-term climate trend studies.

Note that the analyses we performed here do not include other error sources (i.e., cloud radiative effect, ventilation, and sensor orientation, metadata errors) mentioned by Dirksen et al. (2014). Since it is not possible to investigate these errors, we assume these errors introduce more or less random errors when a relative large sample is used. In addition, although RO-derived dry temperature data are not directly traceable to the international standard of units (SI traceability), it has been shown that the high precision nature of the basic RO observations of time delay and bending angle are preserved through the inversion procedures (Ho et al., 2009a, 2011). This makes RO-derived dry temperature uniquely useful for assessing the radiosonde temperature biases and their long-term stability including the seasonal and interannual variability in the lower stratosphere. Results from this study also demonstrate the potential usage of RO data to identify RAOB temperature biases for different sensor types.

Data availability. The RAOB data used in this study are downloaded from https://rda.ucar.edu/datasets/ds351.0/. These data were originally operationally collected by the National Centers for Environmental Prediction, National Weather Service, NOAA, US Department of Commerce and Satellite Services Division, Office of Satellite Data Processing and Distribution, NESDIS, NOAA, USA. The RO data are from the COSMIC Data Analysis and Archive Center, Constellation Observing System for Meteorology, Ionosphere and Climate, University Corporation for Atmospheric Research. Atmospheric profiles are from COSMIC Occultation Data, COSMIC Data Analysis and Archive Center (http://cdaac-www.cosmic.ucar. edu/cdaac/products.html).

Competing interests. The authors declare that they have no conflict of interest.

Acknowledgements. We thank Douglas Hunt from COSMIC team at UCAR for providing COSMIC and Metop-A/GRAS reprocessed temperature data. We also thank reviewers' valuable comments. Special thanks go to the first reviewer, Rick Anthes. His review and comments improve the quality and readability of this paper dramatically. This work is supported by the NSF CAS AGS-1033112.

Edited by: R. Müller

Reviewed by: R. Anthes and one anonymous referee

\section{References}

Andrae, U., Sokka, N., and Onogi, K.: The radiosonde temperature bias correction in ERA-40, ERA-40 Project Report Series, 15, 34 pp., 2004.

Anthes, R. A., Bernhardt, P., Chen, Y., Cucurull, L., Dymond, K., Ector, D., Healy, S., Ho, S.-P., Hunt, D., Kuo, Y.-H., Liu, H., Manning, K., McCormick, C., Meehan, T., Randel, W., Rocken, C. R., Schreiner, W., Sokolovskiy, S., Syndergaard, S., Thompson, D., Trenberth, K., Wee, T.-K., and Zeng, Z.: The COSMIC/FORMOSAT-3 Mission: Early Results, B. Am. Meteorol. Sci., 89, 313-333, 2008.

COSMIC Data Analysis and Archive Center: Atmospheric Profiles from COSMIC Occultation Data, http://cdaac-www.cosmic.ucar. edu/cdaac/products.html (last access: 30 March 2015), 2013.

Dach, R., Lutz, S., Walser, P., and Fridez, P. (Eds): Bernese GNSS Software Version 5.2, User manual, Astronomical Institute, Universtiy of Bern, Bern Open Publishing, doi:10.7892/boris.72297, ISBN: 978-3-906813-05-9, 2015.

Dirksen, R. J., Sommer, M., Immler, F. J., Hurst, D. F., Kivi, R., and Vömel, H.: Reference quality upper-air measurements: GRUAN data processing for the Vaisala RS92 radiosonde, Atmos. Meas. Tech., 7, 4463-4490, doi:10.5194/amt-7-4463-2014, 2014.

Durre, I., Reale, T., Carlson, D., Christy, J., Uddstrom, M., Gelman, M., and Thorne, P.: Improving the usefulness of operational radiosonde data, B. Am. Meteorol. Soc., 86, 411-418, doi:10.1175/BAMS-86-3-411, 2005.

Elliott, W. P., Ross, R. J., and Blackmore, W. H.: Recent Changes in NWS Upper-Air Observations with Emphasis on Changes from VIZ to Vaisala Radiosondes, B. Am. Meteorol. Soc., 83, 10031017, 2002.

Foelsche, U., Pirscher, B., Borsche, M., Kirchengast, G., and Wickert, J.: Assessing the climate monitoring utility of radio occultation data: From CHAMP to FORMOSAT3/COSMIC, Terr. Atmos. Ocean. Sci., 20, 155-170, doi:10.3319/TAO.2008.01.14.01(F3C), 2009.

Free, M., Angle, J. K., Durre, I., Lanzante, J., Peterson, T. C., and Seidel, D. J.: Using first differences to reduce inhomogeneity in radiosonde temperature datasets, J. Clim., 17, 4171-4179, 2004.

Free, M., Seidel, D. J., Angell, J. K., Lanzante, J., Durre, I., and Peterson, T. C.: Radiosonde atmospheric temperature products for assessing climate (RATPAC): A new data set of largearea anomaly time series, J. Geophys. Res., 110, D22101, doi:10.1029/2005JD006169, 2005.

Haimberger, L.: Homogenization of radiosonde temperature time series using innovation statistics, J. Clim., 20, 1377-1403, 2007.

Haimberger, L. and Andrae, U.: Radiosonde temperature bias correction in ERA-Interim, ERA Rep. Series, 8, 17 pp., 2011.

Haimberger, L., Tavolato, C., and Sperka, S.: Toward elimination of the warm bias in historic radiosonde temperature records - Some new results from a comprehensive intercomparison of upper-air data, J. Clim., 21, 4587-4606, 2008.

He, W., Ho, S.-P., Chen, H., Zhou, X., Hunt, D., and Kuo, Y.: Assessment of radiosonde temperature measurements in the upper troposphere and lower stratosphere using COSMIC radio occultation data, Geophys. Res. Lett., 36, L17807, doi:10.1029/2009GL038712, 2009.

Ho, S.-P., Kuo, Y. H., Zeng, Z., and Peterson, T.: A Comparison of Lower Stratosphere Temperature from Microwave Measure- 
ments with CHAMP GPS RO Data, Geophys. Res. Lett., 34, L15701, doi:10.1029/2007GL030202, 2007.

Ho, S.-P. et al.: Estimating the Uncertainty of using GPS Radio Occultation Data for Climate Monitoring: Inter-comparison of CHAMP Refractivity Climate Records 2002-2006 from Different Data Centers, J. Geophys. Res., 114, D23107, doi:10.1029/2009JD011969, 2009a.

Ho, S.-P., Goldberg, M., Kuo, Y.-H., Zou, C.-Z., and Schreiner, W.: Calibration of Temperature in the Lower Stratosphere from Microwave Measurements using COSMIC Radio Occultation Data: Preliminary Results, Terr. Atmos. Ocean. Sci., 20, 87-100, doi:10.3319/TAO.2007.12.06.01(F3C), 2009b.

Ho, S.-P., Zhou, X., Kuo, Y.-H., Hunt, D., and Wang, J.-H.: Global Evaluation of Radiosonde Water Vapor Systematic Biases using GPS Radio Occultation from COSMIC and ECMWF Analysis, Remote Sens., 2, 1320-1330, 2010a.

Ho, S.-P., Kuo, Y.-H., Schreiner, W., and Zhou, X.: Using SItraceable Global Positioning System Radio Occultation Measurements for Climate Monitoring, in: States of the Climate in 2009, B. Amer. Meteorol. Sci., 91, S36-S37, 2010 b.

Ho, S.-P., Hunt, D., Steiner, A. K., Mannucci, A. J., Kirchengast, G., Gleisner, H., Heise, S., von Engeln, A., Marquardt, C., Sokolovskiy, S., Schreiner, W., Scherllin-Pirscher, B., Ao, C., Wickert, J., Syndergaard, S., Lauritsen, K., B., Leroy, S., Kursinski, E. R., Kuo, Y.-H., Foelsche, U., Schmidt, T., and Gorbunov, M.: Reproducibility of GPS Radio Occultation Data for Climate Monitoring: Profile-to-Profile Inter-comparison of CHAMP Climate Records 2002 to 2008 from Six Data Centers, J. Geophy. Res., 117, D18111, doi:10.1029/2012JD017665, 2012.

Ho, S.-P., Peng, L., and Hunt, D.: Construction of consistent temperature climate data records in the lower Troposphere using COSMIC, Metop-A/GRAS, and Metop-B/GRAS from 2006 to 2015, Atmos. Meas. Tech., submitted, 2016.

Kobayashi, E., Noto, Y., Wakino, S., Yoshii, H., Ohyoshi, T., Saito, S., and Baba Y.: Comparison of Meisei RS2-91 Rawinsondes and Vaisala RS92-SGP Radiosondes at Tateno for the Data Continuity for Climatic Data Analysis, J. Meteorol. Soc. Jpn., 90, 923945, doi:10.2151/jmsj.2012-605, 2012.

Kuo, Y. H., Wee, T. K., Sokolovskiy, S., Rocken, C., Schreiner, W., and Hunt, D.: Inversion and error estimation of GPS radio occultation data, J. Meteorol. Soc. Jpn., 82, 507-531, 2004.

Lanzante, J. R., Klein, S. A., and Seidel, D. J.: Temporal homogenisation of monthly radiosonde temperature data, Part I: Methodology, J. Clim., 16, 224-240, doi:10.1175/1520-0442(2003)016, 2003

Luers, J. K.: Temperature error of the Vaisala RS90 radiosonde, J. Atmos. Ocean. Technol., 14, 1520-1532, 1997.

Luers, J. K. and Eskridge, R. E.: Temperature corrections for the VIZ and Vaisala radiosondes, J. Appl. Meteor., 34, 1241-1253, 1995.

Luers, J. K. and Eskridge, R. E.: Use of radiosonde temperature data in climate studies, J. Clim., 11, 1002-1019, 1998.

Research Data Archive at the National Center for Atmospheric Research: NCEP ADP Global Upper Air Observational Weather Data, October 1999 - continuing, Computational and Information Systems Laboratory, updated daily, http://rda.ucar.edu/ datasets/ds351.0/ (last access: 30 March 2015), 2004.
Randel, W. J., Smith, A. K., Wu, F., Zhou, C.-Z., and Qian, H.: Stratospheric temperature trends over 1979-2015 derived from combined SSU, MLS, and SABER satellite observations, J. Clim., 29, 4843-4859, doi:10.1175/JCLI-D-15-0629.1, 2016.

Redder, C. R., Luers, J. K., and Eskridge, R. E.: Unexplained Discontinuity in the US Radiosonde Temperature Data, Part II: Stratosphere, J. Atmos. Ocean Tech., 21, 1133-1144, 2004.

Schreiner, W., Sokolovskiy, S., Hunt, D., Rocken, C., and Kuo, Y.-H.: Analysis of GPS radio occultation data from the FORMOSAT-3/COSMIC and Metop/GRAS missions at CDAAC, Atmos. Meas. Tech., 4, 2255-2272, doi:10.5194/amt4-2255-2011, 2011.

Seidel, D. J., Berger, F. H., Immler, F., Sommer, M., Vömel, H., Diamond, H. J., Dykema, J., Goodrich, D., Murray, W., Peterson, T., Sisterson, D., Thorne, P., and Wang, J.: Reference upper-air observations for climate: Rationale, progress, and plans, B. Am. Meteorol. Soc., 90, 361-369, 2009.

Seidel, D. J., Gillett, N. P., Lanzante, J. R., Shine, K. P., and Thorne, P. W.: Stratospheric tem- perature trends: Our evolving understanding, Wiley Interdisciplinary Reviews, 2, 592-616, 2011.

Sherwood, S. C., Meyer, C. L., Allen, R. J., and Titchner, H. A.: Robust tropospheric warming as revealed by iteratively homogenized radiosonde data, J. Clim., 21, 5336-5352, 2008.

Smith, E. K. and Weintraub, S.: The constants in the equation for atmospheric refractive index at radio frequencies, J. Res. Natl. Bur. Stand., 50, 39-41, 1953.

Sun, B., Reale, A., Seidel, D. J., and Hunt, D. C.: Comparing radiosonde and COSMIC atmospheric profile data to quantify differences among radiosonde types and the effects of imperfect collocation on comparison statistics, J. Geophys. Res., 115, D23104, doi:10.1029/2010JD014457, 2010.

Sun, B., Reale, A., Schroeder, S., Seidel, D. J., and Ballish, B.: Toward improved corrections for radiation-induced biases in radiosonde temperature observations, J. Geophys. Res., 118, 42314243, doi:10.1002/jgrd.50369, 2013.

Thorne, P. W., Parker, D. E., Christy, J. R., and Mears, C. A.: Uncertainties in climate trends: Lessons from upper-air temperature records, B. Am. Meteorol. Soc., 86, 1437-1442, doi:10.1175/BAMS-86-10-1437, 2005.

Thorne, P. W., Brohan, P., Titchner, H. A., McCarthy, M. P., Sherwood, S. C., Peterson, T. C., Haimberger, L., Parker, D. E., Tett, S. F. B., Santer, B. D., Fereday, D. R., and Kennedy, J. J.: A quantification of uncertainties in historical tropical tropospheric temperature trends from radiosondes, J. Geophys. Res., 116, D12116, doi:10.1029/2010JD015487, 2011.

Ware, R., Exner, M., Feng, D., Gorbunov, M., Hardy, K., Herman, B., Kuo, Y., Meehan, T., Melbourne, W., Rocken, C., Schreiner, W., Sokolovskiy, S., Solheim, F., Zou, X., Anthes, R., Businger, S., and Trenberth, K.: GPS sounding of the atmosphere from low Earth orbit: Preliminary results, B. Am. Meteorol. Soc., 77, 1940, doi:10.1175/1520-0477, 1996.

Wei, L.: Performance analysis for China-made bead resistance temperature sensors, Journal of Nanjing University of Information Science and Technology, Natural Science Edition, 3, 346-353, 2011. 